Winter 2013

\title{
The Movement of U.S. Criminal and Administrative Law: Processes of Transplanting and Translating
}

\section{Toby S. Goldbach}

Cornell University Law School, tsg36@cornell.edu

\section{Benjamin Brake}

Cornell University Law School, btb33@cornell.edu

Peter Katzenstein

Cornell University, pjk2@cornell.edu

Follow this and additional works at: https://www.repository.law.indiana.edu/ijgls

Part of the Administrative Law Commons, Criminal Law Commons, and the International Law Commons

\section{Recommended Citation}

Goldbach, Toby S.; Brake, Benjamin; and Katzenstein, Peter (2013) "The Movement of U.S. Criminal and Administrative Law: Processes of Transplanting and Translating," Indiana Journal of Global Legal Studies: Vol. 20 : Iss. 1 , Article 6.

Available at: https://www.repository.law.indiana.edu/ijgls/vol20/iss1/6

This Symposium is brought to you for free and open access by the Law School Journals at Digital Repository @ Maurer Law. It has been accepted for inclusion in Indiana Journal of Global Legal Studies by an authorized editor of Digital Repository @ Maurer Law. For more information, please contact rvaughan@indiana.edu.

\section{$\Psi$}

JEROME HALL LAW LIBRARY

INDIANA UNIVERSITY

Maurer School of Law
Bloomington 


\title{
The Movement of U.S. Criminal and Administrative Law: Processes of Transplanting and Translating
}

\author{
TOBY S. GOLDBACH* \\ BENJAMIN BRAKE* \\ PETER J. KATZENSTEIN ${ }^{\star \star \star}$
}

\begin{abstract}
This article examines the transplanting and translating of law in the domains of criminal procedure and administrative law. The transnational movement of law is full of unexpected twists and turns that belie the notion of the United States as a legal behemoth. Furthermore, the movement of legal procedures which occurs both within and across countries with common and civil law legal traditions challenges preconceived notions of an orderly divide between legal families. While the spread of elements of the U.S. jury system and methods of plea bargaining reveals the powerful influence of U.S. legal ideas, the ways that these procedures undergo processes of translation also illustrates the growing prevalence of legal syncretism. The uneven record of transplanting and translating principles of U.S. domestic administrative law into international organizations exemplifies pluralism in the absence of a global legal hegemon. Our aim is to draw attention to the interaction between international and domestic legal factors and to show that multiple legal products shape processes of
\end{abstract}

* Toby S. Goldbach, B.A., LL.M. is a candidate for the Doctor of the Science of Law (J.S.D.) at Cornell University Law School and was the Rudolf B. Schlesinger Research Fellow for 2011-2012. We would like to thank Mitchel Lasser, Valerie Hans, and Aziz Rana for helpful conversations and advice, and Fred Aman, Mitchel Lasser, Jens Meierhenrich, and Maximo Langer for generously reading an earlier draft of this article in mid-summer and on short notice, and giving excellent criticisms and suggestions.

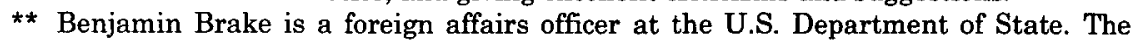
views expressed in this paper are his own and do not necessarily reflect those of the Department of State or the U.S. Government.

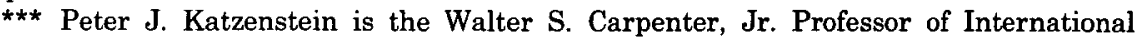
Studies at Cornell University.

Indiana Journal of Global Legal Studies Vol. 20, Issue 1 (2013)

(C) Indiana University Maurer School of Law 
transplanting and translating, thus creating a polymorphic legal world often characterized by syncretic practices. The new normal is broad consultation of a range of international models and a facility for translating multiple or even conflicting legal practices. This presents opportunities for positive legal change and complicates efforts to locate clear sources of power in the movement of law.

\section{INTRODUCTION}

Law is defined by incessant movement involving state and nonstate actors operating in a world that is both international and transnational. Legal transplanting and translating are central aspects of that world. ${ }^{1}$ We focus here specifically on transplanting and translating criminal and administrative legal procedures. ${ }^{2}$ In the era of the primacy of the United

1. See generally ALAN WatSON, Legal TRANSPLANTS: AN APPROACH to COMPARATIVE LAW (1974) (examining historical transplanting of rules); Michele Graziadei, Comparative Law as the Study of Transplants and Receptions, in OXFORD HANDBOOK OF COMPARATIVE LAW 441 (Mathias Reimann \& Reinhard Zimmermann eds., 2006); Gianmaria Ajani, By Chance and Prestige: Legal Transplants in Russia and Eastern Europe, 43 AM. J. CoMP. L. 93 (1995); Louis F. Del Duca \& Alain A. Levasseur, Impact of Legal Culture and Legal Transplants on the Evolution of the U.S. Legal System, 58 AM. J. CoMP. L. 1 (2010); Amalia D. Kessler, Limited Liability in Context: Lessons from the French Origins of the American Limited Partnership, 32 J. LEGAL STUD. 511 (2003); Jonathan B. Wiener, Something Borrowed for Something Blue: Legal Transplants and the Evolution of Global Environmental Law, 27 ECOLOGY L. Q. 1295 (2001).

2. We have chosen to address a specific part of comparative public law in full awareness that we are not dealing with the global movement of constitutional law, which is one of the most important areas of public law legal transplants. See generally RAN HIRSCHL, TOWARDS JURISTOCRACY: THE ORIGINS \& CONSEQUENCES OF THE NEW CONSTITUTIONALISM 11-12 (2004) (arguing that increased powers of judicial review is a product of a strategic interplay between threatened political elites, economic elites, and judicial elites and national high courts; constitutionalization of rights is "often not a reflection of a genuinely progressive revolution in a polity; rather, it is evidence that the rhetoric of rights and judicial review has been appropriated by threatened elites to bolster their own position in the polity"); THE MigRation OF CONSTITUTIOnal IDEAS (Sujit Choudhry ed., 2006); Bruce Ackerman, The New Separation of Powers, 113 HaRv. L. REv. 633, 636-40 (2000) (arguing against the export of the U.S. constitutional system and in favor of Parliamentarianism and the constitutional systems of Germany, Italy, Japan, India, Canada, and South Africa, with the German constitution in particular having inspired other countries transitioning from authoritarianism); Jacco Bomhoff, Balancing, the Global and the Local: Judicial Balancing As a Problematic Topic in Comparative (Constitutional) Law, 31 HaSTINGS INT'L \& CoMP. L. REv. 555 (2008); Ran Hirschl, The Realist Turn in Comparative Constitutional Politics, 62 POL. RES. Q. 825 (2009) (discussing realist and contextualist explanations of constitutional courts and judicial review); Alec Stone Sweet, Constitutionalism, Legal Pluralism, and International Regimes, 16 IND. J. GloBAL LEGAL STUD. 621, 633-36 (2009) (arguing that multiple high courts assert jurisdiction over constitutional norms, including specialized constitutional 
States during the second half of the twentieth century, U.S. influence on and involvement in the movement of law has been substantial, yet limited. ${ }^{3}$ Although the United States' expansive influence is undeniable in many domains of law, its influence is neither direct nor simple. Transplanting and translating law in the domains of criminal procedure and administrative law are marked by unexpected twists and turns that belie the notion of a U.S. legal behemoth calling the shots in a system of legal imperialism. ${ }^{4}$ The movement that does occur, both within and across countries with civil and common-law legal traditions, challenges an orderly divide between legal families. ${ }^{5}$

In the area of criminal procedure, elements of the jury system and methods of plea bargaining, once defining features of the U.S. legal system, have spread far and wide across civil and common-law systems and into the far-reaches of a world marked increasingly by legal syncretism. ${ }^{6}$ On the other hand, an uneven record of transplanting and

courts and national courts that incorporate the European Court of Justice's constitutional doctrines).

3. See generally Benjamin Brake \& Peter J. Katzenstein, Lost in Translation? Non-State Actors and the Transnational Movement of Procedural Law, 67 INT'L ORG. 4 (forthcoming October 2013) (describing the movement of the U.S. class action and discovery process; the movement of U.S. law has reshaped legal theory, pedagogy, procedure, and the organizing structure of the legal profession, however Americanization competes with other forces, including Europeanization, Islamicization, Sinicization, Indianization, and Japanization); but see Richard O. Lempert, The Internationalization of Lay Decision-Making: Jury Resurgence and Jury Research, 40 CORNELL INT'L L.J. 477, 478 (2007) (examining that while domestically in the U.S., reforms aimed at reducing the jury's jurisdiction, internationally, the common law jurisdictions, as well as former Soviet countries, enacted reforms to establish or reestablish U.S-style jury systems).

4. See generally JAMES A. GARDNER, LEGAL IMPERIALISM: AMERICAN LAWYERS AND ForEIGN AID IN LATIN AMERICA 8-9 (1980) (discussing the unsuccessful attempts to transplant and develop U.S. legal frameworks in developing countries, due to a lack of understanding "local language, law, polity, economy, or culture").

5. H. Patrick Glenn, Comparative Legal Families and Comparative Legal Traditions, in THE OXFORD HANDBOOK OF COMPARATIVE LAW, supra note 1, at 421, 422; John Henry Merryman, On the Convergence (and Divergence) of Civil Law and the Common Law, 17 STAN. J. INT'L L. 357, 380-382 (1981); see generally MITCHEL DE S.-O.-L'E. LASSER, JUdicial Deliberations: a COMPARATIVE ANALYSis OF JUdicial TRANSPARENCY AND LEGITIMACY (2004) (arguing that both French civilian and U.S. common law judges apply textually formal and pragmatic modes of interpretation; approaches may differ, but judges have common concerns around issues of transparency, judicial accountability, and democratic debate and deliberation); JOHN HENRY MERRYMAN, THE CIVIL LAW TRADITION: AN INTRODUCTION TO THE LEGAL SYSTEMS OF WESTERN EUROPE AND LATIN AMERICA (1985) (arguing that there is diversity in civilian systems). But see Ralf Michaels, Two Paradigms of Jurisdiction, 27 MICH. J. INT'L L. 1003, 1007 (2006) (arguing that U.S. and European approaches to jurisdiction are "strikingly different").

6. Legal systems adopt a mix of rules and procedures that hail from multiple sources. Jurisdictions, especially in East Asia, have incorporated both common law (jury) and civil-law (lay judge) transplants. See, e.g., Ryan Y. Park, The Globalizing Jury Trial: 
translating principles of domestic administrative law into international organizations exemplifies competition in the absence of a global legal hegemon. ${ }^{7}$ This disparity of influence in different domains of law emerges in part because global governance models lack clear executive or legislative functions of government. ${ }^{8}$ Even without structural

Lessons and Insights from Korea, 58 AM. J. COMP. L. 525, 532-33 (2010) (discussing South Korea's "hybrid institutional design"); see discussion, infra Section II.

7. On the decline of the United States as a global hegemon and the effect on the international system see generally ROBERT O. KEOHANE, AFTER HEGEMONY: COOPERATION AND DISCORD IN THE WORLD POLITICAL ECONOMY (1984) (arguing that international sectoral regimes persist and affect patterns of cooperation in the absence of U.S. hegemony). On the lack of a unified global legal framework see Andreas Fischer-Lescano \& Gunther Teubner, Regime-Collisions: The Vain Search for Legal Unity in The Fragmentation of Global Law, 25 MICH. J. INT'L L. 999, 1004, 1008-09 (Michelle Everson trans., 2004) (arguing that global legal fragmentation is "the expression of deep contradictions between colliding sectors of the global society"; transnational legal regimes define their jurisdiction along issue-specific rather than territorial lines). Challenging the claim that U.S. law currently has hegemonic status, German public law with its emphasis on proportionality serves as an example for public law systems. See, e.g., Susan RoseAckerman, American Administrative Law Under Siege: Is Germany a Model?, 107 Harv. L. Rev. 1279 (1994) (comparing U.S. administrative law system, which focuses on oversight of executive processes, to German public law system, which focuses on the protection of individual rights against the state, in light of U.S. problems of judicial activism). Japan adopted the German Commercial Code in modified form, and generally the German legal tradition influenced several European and East-Asian countries. See Rafael La Porta, Forencio Lopez-de-Silanes \& Andrei Shleifer, The Economic Consequences of Legal Origins, $46 \mathrm{~J}$. ECON. LITERATURE 285, 290 (2008). On the movement of administrative law into international organizations, see discussion, infra Section III.

8. It is axiomatic that the international sphere is not governed by a centralized body which performs executive and legislative functions. See generally HEDLEY BULL, THE ANARCHICAL SOCIETY: A STUDY OF ORDER IN WORLD POLITICS (1977); KENNETH N. WALTZ, THEORY OF INTERNATIONAL POLITICS 93 (1979) (In domestic politics, "Congress makes the laws; the executive branch enforces them; agencies administer laws; [and] judges interpret them." In contrast, the international political system contains like units (e.g. states) that are not differentiated by the functions they perform: "Anarchy entails relations of coordination among a system's units, and that implies their sameness."). Legal and international relations theorists who challenge the realist account of exogenous structure formation and state-centric versions of governance include Anne-Marie Slaughter, Breaking Out: The Proliferation of Actors in the International System, in GLOBAL Prescriptions: The Production, Exportation, and Importation of a NEW LEgal ORTHodoxy 12, 28 (Yves Dezalay \& Bryant G. Garth eds., 2002) (advocating for a perspective that "disaggregate[s] the state," and identifies the components of the international system based on "common governance functions rather than reified unites of power"); John Gerard Ruggie, What Makes the World Hang Together? Neo-Utilitarianism and the Social Constructivist Challenge, 52 INT'L ORG. 855, 871, 875 (1998) (arguing that constitutive rules are needed to explain the origins of international relations and to rescue structure from being treated "as the reified residue left behind by long-ceased historical processes"); Alexander Wendt, Anarchy Is What States Make of It: The Social Construction of Power Politics, 46 INT'L ORG. 391, 394-95 (1992) (arguing that "anarchy" in the international system does not exist apart from the practices that create structures of 
impediments, the transnational movement of U.S. administrative law confronts competition and co-optation in articulating or controlling the legal landscape. ${ }^{9}$

The intent of this paper is to offer a nuanced view of the movement of law, transplants, and translation. This paper takes inspiration from works that question definitive categories, ${ }^{10}$ look to social processes in the movement of law, 11 and challenge scholars to be self-reflective about their own connections to issues of governance and intellectual histories. ${ }^{12}$ Although some of this is not new, legal transplant literature maintains an awkward relationship to issues of governance and history. ${ }^{13}$ Scholarship still unfolds largely "in the shadow of"14 Alan Watson, ${ }^{15}$ telling a story of how local and national culture matter to law's implementation, or of the extent to which legal families play a role in the reception of foreign law. Legal transplant scholars tend to downplay conflict and competition in the movement of law, ${ }^{16}$ and remain

identities and interests); Gunther Teubner, Breaking Frames: The Global Interplay of Legal and Social System, 45 AM. J. COMP. L. 149, 149, 157 (1997) (describing how various sectors of world society, including multinational enterprises, labor, human rights, and the internet, are "breaking the narrow frame of national law" and developing a global law in isolation from the state).

9. On competition in the transnational movement of administrative law, see discussion, infra Section III(A).

10. See, e.g., ANnElise RILES, Collateral KNOWLEDGE (2011).

11. See, e.g., LAWYERS AND THE RULE of LAW IN AN ERA OF Globalization (Yves Dezalay \& Bryant G. Garth eds., 2011).

12. See generally David Kennedy, New Approaches to Comparative Law: Comparativism and International Governance, 2 UTAH L. REV. 545, 592-606 (1997) (asking to uncover connections that have led to governance through "distance, denial, and avoidance"); Peer Zumbansen, Transnational Comparisons: Theory and Practice of Comparative Law as a Critique of Global Governance, in PRACTICE AND THEORY IN COMPARATIVE LAW 186 (Maurice Adams \& Jacco Bomhoff eds., 2012) (examining comparative law's meanings and methods of inquiry along with current debates about context of comparative and transnational law).

13. Kennedy, supra note 12 , at 554 ("[C]omparative law ... see[s] itself as precisely not about politics or governance, as existing rather in the realm of history or thought, as an intellectual project of understanding between cultures whose similarities and differences are foregrounded." Matters of intercultural struggles are background.).

14. See Robert H. Mnookin \& Lewis Kornhauser, Bargaining in the Shadow of the Law: The Case of Divorce, 88 YALE L.J. 950 (1979).

15. See, e.g., William Ewald, Comparative Jurisprudence (II): The Logic of Legal Transplants, 43 AM. J. COMP. L. 489, 489-92 (1995) (examining and applying Watson's theory); Michele Graziadei, Legal Transplants and the Frontiers of Legal Knowledge, 10 THEORETICAL INQUIRIES IN L. 723, 726 (2009) (discussing Watson's publications).

16. Legal transplant scholars focus on whether foreign legal systems can incorporate transplants and generally fall into two camps: a cultural connection does or does not matter. Examples of scholars in the first camp include Pierre Legrand, The Impossibility of 'Legal Transplants,' 4 MAASTRICHT J. EUR. \& COMP. L. 111 (1997), and Maximo Langer, From Legal Transplants to Legal Translations: The Globalization of Plea Bargaining and 
quiet about contestations in cultures that are fluid. ${ }^{17}$ Our aim is to draw attention to the interaction between international and domestic legal factors, and to show that multiple legal products impact processes of transplanting and translating, creating a polymorphic legal world often characterized by syncretic practices.

Tracking the spread of public law offers unique insights into processes of transplanting and translating law and legal procedures. Compared to private law, public law is especially connected to state policy, security, and organizational choices. ${ }^{18}$ In other words, it is located closer to the "organic" end of the rules spectrum and therefore more resistant to being transplanted. ${ }^{19}$ For reasons of length, this article attends only to the domestic aspects of criminal procedure and the international features of administrative law. A comprehensive treatment of both the domestic and international aspects of transplanting and translating these legal domains must be left to others. This article's intent, instead, is to deploy and broaden a sociological perspective on the movement of law, 20 in order to challenge both hegemonic or imperialist legal domination models and cultural or structural legal families' models. This article develops its conceptual

the Americanization Thesis in Criminal Procedure, 45 HARV. INT'L L.J. 1 (2004). WATSON, supra note 1 , typifies the second camp. What is missing in both literatures is a detailed account of how legal change occurs-the details, processes, and minutia of unpacking transplants. Dezalay \& Garth have been involved in several research projects looking into "competitive processes" implicated in the movement of law, in particular in "creating and maintaining a demand for transnational norms." See Yves Dezalay \& Bryant G. Garth, Marketing and Selling Transnational 'Judges' and Global 'Experts': Building the Credibility of (Quasi)Judicial Regulation, 8 SOCIO-ECON. REV. 113, 114-15 (2010); YVES Dezalay \& BRYaNT G. GarTh, The InTERnationalization of Palace Wars: LaWyers, ECONOMISTS, AND THE CONTEST TO TRANSFORM LATIN AMERICAN STATES (2002); GLOBAL Prescriptions: The Production, Exportation, and ImPortation of a New Legal ORTHODOXY, supra note 8; Yves Dezalay \& Bryant G. Garth, Marketing and Legitimating Two Sides of Transnational Justice: Possible Trajectories Toward a Unified Transnational Field, in LAWYERS AND THE CONSTRUCTION OF TRANSNATIONAL JUSTICE 277 (Yves Dezalay \& Bryant G. Garth eds., 2012).

17. Annelise Riles critiques the legal pluralist approach which "treats cultural diversity simply as an increase in the quantity of communities" rather than embracing contemporary anthropological understandings that culture is hybrid and fluid: "culture' is more of a constant act of translation and re-creation or re-presentation than it is a fixed and given thing." Annelise Riles, Cultural Conflicts, 71 LAW \& CONTEMP. PROBS. 273, 285, 295 (2008). Legal transplant scholars similarly treat diversity in legal transplants as manifesting through local cultural resistance to foreign legal norms rather than competing and contradicting processes of reception.

18. See RILES, supra note 10, at 42, 171 (regarding the lack of neat distinctions between private and public law).

19. Otto Kahn-Freund, On Uses and Misuses of Comparative Law, 37 MoD. L. REv. 1, 17 (1974).

20. See Brake \& Katzenstein, supra note 3. 
language in Part $\mathrm{I}$, and discusses domestic criminal procedure and international administrative law, respectively, in Parts II and III. It ends with brief sketches of what an analysis of international criminal procedure and domestic administrative law might look like and what this tells us more generally about contemporary movements of law.

\section{TRANSPLANTING AND TRANSLATING LAW}

Whether law migrates horizontally across legal systems, standardizes legal approaches to common concerns, ${ }^{21}$ or moves by other means, transplanting and translating are part of that process. Both transplanting and translating are captured best by an interactional perspective on the movement of law. In this view, states, corporations, international governmental and non-governmental organizations, and individuals interact in various transnational arenas to make, unmake, and remake law. ${ }^{22}$ An interactional perspective stresses the coevolution and commingling of local and domestic as well as international and transnational legal norms and practices. ${ }^{23}$

Harold Koh, Alec Stone Sweet, and Jutta Brunnée and Stephen Toope offer different but related formulations of such a perspective. For Harold Koh, transnational legal processes break down the sharp distinction between domestic and international affairs. ${ }^{24}$ Laws percolate in all directions-upward, downward, and sideways-and thus connect different legal arenas and actors. This movement encounters actors capable of self-reflection, thus permitting the emergence and

21. See, e.g., Kim Lane Scheppele, The International Standardization of National Security Law, 4 J. NAT'L SECURITY L. \& POL'Y 437 (2010) (examining how multiple countries adopted similar antiterrorism laws after 9/11).

22. JUTTA BRUNNÉE \& STEPHEN J. TOOPE, LEGITIMACY AND LEGALITY IN INTERNATIONAL LAW: AN INTERACTIONAL ACCOUNT 20-23 (2010); Gregory Shaffer, Transnational Legal Process and State Change, 37 LAW \& SOC. INQUIRY 229, 229-30 (2012); see Jutta Brunnée \& Stephen J. Toope, The Use of Force: International Law After Iraq, 53 INT'L \& COMP. L.Q. 785, 801-04 (describing the involvement of NGOs and international organizations in conversations about the development of humanitarian intervention as a legal justification for the use of force in international law); Terence Halliday \& Gregory Shaffer, Transnational Legal Orders (May 2012) (unpublished paper) (on file with author) (arguing that industry invention, transformations in national economies, or even changes in leadership of international organizations are all factors in the transformation of transnational legal orders); see generally TRANSNATIONAL LEGAL ORDERING AND STATE CHANGE (Gregory C. Shaffer ed., 2013).

23. See Kennedy, supra note 12 , at $\mathbf{5 5 4}$.

24. See Harold Hongju Koh, Transnational Legal Process, 75 NEB. L. REV. 181, 184 (1996). 
internationalization of new legal norms. ${ }^{25}$ For Alec Stone Sweet, the movement of law in dyadic contracting arrangements evolves into triadic dispute resolution mechanisms that, over time, filter back into reasoning processes and legal practices. ${ }^{26}$ Utility-maximizing strategies at any one time thus blend over into slowly evolving normative arrangements. In this view, law does not need to be internalized to become effective. Instead, law is an evolving arrangement that manages conflict and enables actors to contract, dispute, argue, and persuade one another. ${ }^{27}$ Finally, Jutta Brunnée and Stephen Toope focus on decentralized communities of legal practice that are grounded not in codified norms legislated by states as much as in shared social understandings. ${ }^{28}$ Criteria of legality interior to the law create legal obligation and push actors toward adherence of legal norms. ${ }^{29}$

Although different in focus, all three accounts emphasize interaction in the movement of law and stress how transplanting and translating occur through self-interested and normative action that generates legal normativity. For Maximo Langer, transplanting and translating are useful concepts to specify many of the processes by which legal systems interact. $^{30}$ The influence of U.S. legal practices on other systems, he

25. Id. at 186-91 (discussing "exceptionalism through transnational legal process" and referring to exceptionalism as relating to the United States); see Harold Hongju Koh, On American Exceptionalism, 55 STAN. L. REV. 1479, 1501-03 (2003) (discussing "the evolution of transnational legal processes").

26. See Alec Stone Sweet, Judicialization and the Construction of Governance, 32 CoMP. POL. STUD. 147, 164 (Apr. 1999).

27. Id. at 154-55.

28. See BRUNNÉE \& TOOPE, supra note 22 .

29. Id. at 16, 24; Jutta Brunnée \& Stephen J. Toope, Constructivism and International Law, in INTERDISCIPLINARY PERSPECTIVES ON INTERNATIONAL LAW AND INTERNATIONAL Relations: The State of THE ART 119 (Jeffrey L. Dunoff \& Mark A. Pollack eds., 2013); Martha Finnemore \& Stephen J. Toope, Alternatives to "Legalization": Richer Views of Law \& Politics, 55 INT'L ORG. 743, 749-750 (2001) (adopting Fuller's criteria for legitimacy, and arguing that legitimacy generated through attention to internal legal values, including the processes by which law is created and applied, is an essential source of obligation). On the internal criteria of legality, see generally RONALD DWORKIN, TAKING RightS SERIOUSLY (1977); LON L. FUlleR, THE MORALITY OF LAW (1964); RoberT Summers, LoN L. FULLer (1984); Lon L. Fuller, Postivism \& Fidelity to Law: A Reply to Professor Hart, 71 HARV. L. REV. 630 (1958). Fuller's criteria of legality-that in order for something to be law it must be general, proscriptive, publicly accessible, etc.-stands in contrast to Hart's legal positivism, where obligation is felt internally but as a result of social acceptance of rules for creating rules. On legal positivism, see generally H.L.A. HART, The CONCEPT OF LAW (1994); JOSEPH RAZ, PRACTICAL REASON AND NORMS (1990); ScOTT SHAPIRO, LEGALITY (2011); Scott J. Shapiro, What Is the Internal Point of View?, 75 FORDHAM L. REV. 1157 (2006).

30. See Langer, supra note 16 , at $29,31$. 
argues, is not simply a transplant, whereby a transplanted organ continues to function as it did in the original body. Instead, translation evokes the uncertainty of the outcome and the notion that a law's actual practice depends in part on the receiving country's legal language and the decisions of the legal translator. ${ }^{31}$ Langer's case studies include recent reforms in civil law systems toward U.S.-style civil and criminal procedures; these tend to make the judge a more passive actor by strengthening the role of the prosecution and defense in fact finding and in conducting the proceedings themselves. ${ }^{32} \mathrm{He}$ concludes that, because of the different preexisting structures of meaning in different civil law countries (such as Germany, Italy, Argentina, and France) that have imported these procedures, the importation of the same procedure has affected these states' legal systems in varying ways.

\section{A. Transplanting}

The transplant concept points to the complex requirements for recipients and donors for processes of diffusion and reception that reflect the mutually constitutive relations between migratory and local law. ${ }^{33}$ Several decades ago, Alan Watson was among the first to write about the spread and reception of a law and the fit it required between transplanted and local laws. ${ }^{34}$ A successful legal transplant, he noted, typically must overcome significant obstacles to thrive in a new legal system. ${ }^{35}$ In this way, "organic" transplants differ from "mechanical"

31. See Karen Knop, Here and There: International Law in Domestic Courts, 32 N.Y.U. J. INT'L L. \& POL. 501, 506 (2000).

32. Langer, supra note 16, at 40-41, 48 (Italian reforms gave prosecutors and defense attorneys the ability to conduct their own investigations, thereby replacing the preliminary investigation judge as the fact finder in the pretrial phase; but compare with German reforms, where the presiding trial judge is an active participant in pretrial agreements).

33. John Gillespie, Towards a Discursive Analysis of Legal Transfers into Developing East Asia, 40 N.Y.U. J. INT'L L. \& PoL. 657, 685 (2008); Ralf Michaels, Comparative Law by Numbers? Legal Origins Thesis, Doing Business Reports, and the Silence of Traditional Comparative Law, 57 AM. J. CoMP. L. 765, 781 (2009) (Moreover, especially in non-Western countries, Western law has often mixed with domestic legal traditions, resulting in mutual influence."); see generally Daniel Berkowitz, Katharina Pistor \& JeanFrancois Richard, Economic Development, Legality, and the Transplant Effect, 47 EuR. ECON. REV. 165 (2003) (arguing that transplants need to be adapted to local conditions in order to be effective).

34. See Alan Watson, Legal Transplants and Law Reform, 92 L. Q. REv. 79 (1976); Ewald, supra note 15, at 491; William Twining, Social Science and Diffusion of Law, 32 J.L. \& SoC'Y 203, 211-13 (2005).

35. See Watson, supra note 34; see also Pierre Legrand, The Impossibility of Legal 
ones in requiring more attention to local conditions and the character of the proposed legal reform. ${ }^{36}$ The success of a legal transplant depends partly on the act of transplanting, the characteristics that inhere in the transplanted law itself, and the ability to graft onto existing legal norms and practices. ${ }^{37}$ Transplant theory thus directs our attention to the processual character of law in both the exporting and importing legal systems. ${ }^{38}$

The transplanting of foreign laws by some countries, however, reveals a transplant bias, whereby importing state actors operate with an unthinking receptivity to foreign law because of social conditions such as the general prestige, linguistic accessibility, and the training and experience of local lawyers. ${ }^{39}$ Many of these factors have helped the transnational movement of U.S. law. Academic writers typically are most susceptible to the sway of grand foreign theories, whereas those following legal precedents are sometimes more resistant. Judges borrowing foreign rules will carefully weigh the pros and cons, while academics are more likely to be swept away by the logic of an elegant or innovative argument. 40 Economic factors can also play an important role. Economic efficiency has proven to be a powerful engine driving the process of transplanting law in legal domains such as competition and estate law. ${ }^{41}$

The process of transplanting law emphasizes domestic differences, especially between adversarial common law systems and their inquisitorial civil law counterparts. As David Sklansky observed, "if scholars of comparative law agree on anything, it is the hazards of legal

Transplants,' 4 MAASTRICHT J. EUR. \& COMP. L. 111 (1997) (discussing obstacles of such significance that the author views transplants are impossible).

36. See Kahn-Freund, supra note 19, at 5-7.

37. See Sally Engle MerRy, Human Rights and Gender Violence: Translating INTERNATIONAL LAW INTO LOCAL JUSTICE 134-78 (2006); Berkowitz, Pistor, \& Richard, supra note 33 , at 167 .

38. See Yves Dezalay \& Bryant G. Garth, Dealing in VirTue: InTERnational COMMERCIAL ARBITRATION AND THE CONSTRUCTION OF A TRANSNATIONAL LEGAL ORDER (1998) (exploring a variety of case studies involving international business law development and exchange between various countries and how this creates a process of transplanting systems).

39. Alan Watson, Comparative Law and Legal Change, 37 CAMBRIDGE L.J. 313, 327 (1978).

40. See, e.g., Ajani, supra note 1 (exampling a writer discussing legislation in Russia and Eastern Europe in a post-soviet era); Ewald, supra note 15, at 499 (exampling a writer discussing Alan Watson's proposed theory of the growth of law being explained by transplantation of legal rules); Pierre Legrand, Against a European Civil Code, 60 MoD. L. REV. 44 (1997) (exampling a writer discussing European legal integration).

41. Ugo Mattei, Efficiency in Legal Transplants: An Essay in Comparative Law and Economics, 14 INT'L REV. L. \& ECON. 3, 9 (1994) (looking at competition driving transplanting of law through examining trusts). 
transplants," most especially between civil and common-law systems. ${ }^{42}$ Thus, the origin of a transplanted rule is one condition that can affect the process of legal transplanting. In general, transplants occur more readily within, rather than across, legal families. ${ }^{43}$ The institutionalization of different legal cultures accounts for the persistence of legal families over time. ${ }^{44}$ The closer states' legal systems are in terms of cost structure and constitutive rules, the more likely those states are to look to each other for legal innovations. ${ }^{45}$ For example, though they lack an analysis of causal mechanisms specifying how transplants occur, correlational studies have shown a persistent relationship between legal family and observable phenomena such as financial development, ${ }^{46}$ government ownership of banks, ${ }^{47}$ burden of entry regulations, ${ }^{48}$ incidence of military conscription, ${ }^{49}$ government

42. David Alan Sklansky, Anti-Inquisitorialism, 122 HARV. L. REV. 1634, 1678 (2009).

43. For important explorations of this topic, see generally ADAPTING LEGAL CULTURES (David Nelken \& Johannes Feest, eds., 2001) (exploring the theme of changing legal culture by looking at ways cultures interact, influence, and change each other); Mirjan Damaška, The Uncertain Fate of Evidentiary Transplants: Anglo-American and Continental Experiments, 45 AM. J. CoMP. L. 839 (1997) (examining two families of civil procedure); Holger Spamann, Contemporary Legal Transplants: Legal Families and the Diffusion of (Corporate) Law, 2009 BYU L. REV. 1813 (2009) (examining corporate and securities laws empirically to find diffusion of materials from core countries to periphery countries); Wolfgang Wiegand, The Reception of American Law in Europe, 39 AM. J. CoMP. L. 229 (1991) (looking generally at Swiss law).

44. See La Porta, Lopez-de-Silanes \& Shleifer, supra note 7, at 286, 306-07 ("Legal Origins Theory has three basic ingredients": (1) England and Continental Europe, particularly France, developed different methods to control business, (2) these styles of control and their corresponding legal institutions were transplanted to most of the world, and (3) although legal and regulatory change has occurred, these styles have proved persistent).

45. Aron Balas, Rafael La Porta, Florencio Lopez-de-Silanes \& Andrei Shleifer, The Divergence of Legal Procedures, 1 AM. ECON. J.: ECON. POL. 138 (2009).

46. See Rafael La Porta, Florencio Lopez-de-Silanes, Andrei Shleifer, \& Robert Vishny, Legal Determinants of External Finance, 52 J. FIN. 1131, 1149 (1997) (showing in a study of 49 countries, civil-law countries, in particular those countries that had inherited French civil-law, had weaker investor protections and less developed capital markets as compared to common law countries).

47. See, e.g. Rafael La Porta, Florencio Lopez-de-Silanes \& Andrei Shleifer, Government Ownership of Banks, 57 J. FIN. 265 (2002).

48. See, e.g. Simeon Djankov, Rafael La Porta, Florencio Lopez-de-Silanes \& Andrei Shleifer, The Regulation of Entry, 117 Q. J. ECON. 1 (2002).

49. See, e.g., Casey B. Mulligan \& Andrei Shleifer, Conscription as Regulation, 7 AM. L. \& ECON. REV. 85 (2005); Casey B. Mulligan \& Andrei Shleifer, The Extent of the Market and the Supply of Regulation, 120 Q. J. ECON. 1445 (2005). 
ownership of the media, ${ }^{50}$ formalism of judicial procedures, ${ }^{51}$ and judicial independence. ${ }^{52}$

However, in a world of hybridization and syncretism with increasing transnational and international engagement, legal family is not destiny. ${ }^{53}$ Locating local law is no easier than identifying the causes, character, and consequences of processes of legal transplanting. Valuable historical scholarship has analyzed the distorting roles many colonial and neocolonial missionaries played in the outright fabrication of "indigenous" and "customary" local law. ${ }^{54}$ Much of what was treated by colonial jurists as extant local dispute resolution procedures was instead a political fabrication involving the converging interests of colonial officials and local elites. ${ }^{55}$ In the nineteenth century, it was

50. See, e.g. Simeon Djankov, Caralee McLiesh, Tatiana Nenova \& Andrei Shleifer, Who Owns the Media?, 46 J.L. \& ECON. 341 (2003).

51. See, e.g. Simeon Djankov, Rafael La Porta, Florencio Lopez-de-Silanes \& Andrei Shleifer, Courts, 118 Q. J. ECON. 453 (2003).

52. See Rafael La Porta, Florencio Lopez-de-Silanes, Christian Pop-Eleches \& Andrei Shleifer, Judicial Checks and Balances, 112 J. POL. ECON. 445 (2004). For a review of country studies and the legal origin effects on particular areas of law, see generally La Porta, Lopez-de-Silanes \& Shleifer, supra note 7, at 292-93. These "legal origin" studies were attempts to find empirical support for institutional theories, which suggest that strong legal institutions are important prerequisites to economic development. See, e.g., DOUGlas C. NORTH, INSTITUTIONS, INSTITUTIONAL CHANGE AND ECONOMIC PERFoRMANCE (1990). These studies, however, have received much criticism, including: (a) that the coding of countries in the 1997 paper was shown to be erroneous; see, e.g., Michaels, supra note 33 , at $770-71$ (recoded, common law origins were no longer superior); (b) that the studies do not account for a "transplant effect"; see Berkowitz, Pistor \& Richard, supra note 33 , at 166 (the way law is transplanted and received is a stronger determinant of economic development than the legal origin theory); and (c) that legal origin studies do not account for subsequent reactions and interactions of and resultant institutional arrangements in colonial territories; see Ronald J. Daniels, Michael J. Trebilcock \& Lindsey D. Carson, The Legacy of Empire: The Common Law Inheritance and Commitments to Legality in Former British Colonies, 59 AM. J. CoMP. L. 111, 126 (2011) ("the colonial experience rather than the initial conditions of the colonized regions proves the decisive independent variable"). See also Curtis J. Milhaupt, Beyond Legal Origin: Rethinking Law's Relationship to the Economy-Implications for Policy, 57 AM. J. CoMP. L. 831 (2009).

53. See Daniels, Trebilcock \& Carson, supra note 52, at 174.

54. See Martin Chanock, The Law Market: the Legal Encounter in British East and Central Africa, in EUROPEAN EXPANSION AND LAW: THE ENCOUNTER OF EUROPEAN AND INDIGENOUS LAW IN 19TH AND 20TH CENTURY AFRICA AND ASIAN 279 (W.J. Mommsen \& J.A. de Moor eds., 1992); MARTIN CHANOCK, THE MAKING OF SOUTH AFriCAN LEGAL Culture, 1902-36: Fear, Favour, AND PreJudice 248, 252 (2001); Laura Nader, HARMONY IDEOLOGY: JUSTICE AND CONTROL IN A ZAPOTEC MOUNTAIN VILLAGE 10, 307 (1990); Francis G. Snyder, Colonialism and Legal Form: The Creation of Customary Law in Senegal, 19 J. LeGal PluRalism 49, 60 (1981).

55. T.W. Bennett, Comparative Law and African Customary Law, in OxForD 
quite difficult to "subtract the influence of the colonial system to unearth the 'real' authentic one." 56 This is even truer today. The autonomous internal development of a legal system, thus, is very much the exception, not the rule. ${ }^{57}$ Moreover, in the long-term, such exceptions create effective legal institutions and practices only when transplanted law is not imposed or copied, but developed internally through a process of trial and error. ${ }^{58}$ Few countries were born lucky. In most instances states have inherited their legal order from one of the existing legal families, either through forcible imposition, voluntary imitation, or more or less creative adaptation. 59

Today, it is rare that a dispute arises anywhere in the world in which a party can rightfully appeal to a self-contained legal system. Profoundly affected by transnational legal processes, laws within a single system typically derive from various sources and are thoroughly intertwined with one another. Legal syncretism through the

HaNDBooK of Comparative LaW, supra note 1, at 641, 665; Peter Fitzpatrick, Traditionalism and Traditional Law, 28 J. AFR. L. 20, 23 (1984); Sally Engle Merry, Law and Colonialism, 25 LAW \& SOC'Y REv. 889, 893 (1991) ('“customary law' was a product of the colonial period, shaped by the efforts of 'native' modernizing elites" and European officials); Ralf Michaels, Global Legal Pluralism, 5 ANN. REv. L. \& Soc. ScI. 243, 254-55 (2009) (surveying the literature of the colonial construction or recognition of nonstate law: "The creation of colonial law was neither an innocuous nor a nonviolent act: For the colonizers, it created an order that was categorically similar and thus could be subjected to their own law; for the elites among the colonized, it opened up avenues toward reaffirming their own power"); Francis Snyder, Customary Law and the Economy, 28 J. AFR. L. 34, 35 (1984) ("the notion of customary law was an ideology of colonial domination"); see Chanock, The Making of South African Legal CUlture, 1902-36: FEAR, Favour, AND PREJUDICE, supra note 54, at 34, 245-48; NADER, supra note 54, at 2, 5-6.

56. Sally Engle Merry, From Law and Colonialism to Law and Globalization, 28 LAW \& SOC. INQ. 570, 572 (2003) (reviewing MARTIN CHANOCK, LAW, CUSTOM, AND SOCIAL ORDER: THE Colonial EXPERIEnCE IN MALAWI AND Zambia (1998)); see also Amr Shalakany, Sanhuri and the Historical Origins of Comparative Law in the Arab World (or How Sometimes Losing your Asalah can be Good for You), in RETHINKING THE MASTERS OF COMPARATIVE LAW 157, 182 (Annelise Riles ed., 2001) ("[N]ostalgia for a return to a more authentic cultural past is itself an intellectually futile exercise-in the postcolonial world we live in, there is no going back to a precolonial home.").

57. See Rodolfo Sacco, Legal Formants: A Dynamic Approach to Comparative Law (Installment I of II), 39 AM. J. CoMP. L. 1, 11 (1991).

58. See Berkowitz, Pistor \& Richard, supra note 33, at 167.

59. La Porta, Lopez-de-Silanes, Shleifer, \& Vishny, supra note 46, at 1131-32 ("Most countries have adopted their legal systems through occupation or colonization by one of the European powers to which they owe the origin of their laws"); La Porta, Lopez-de-Silanes \& Shleifer, supra note 7, at 290, 307 (although there are exceptions, including Japan, which voluntarily adopted the German legal system, and some Latin American countries, which were influenced by the French legal tradition after independence, the majority of legal transplants "is the product of conquest and colonization"); see generally Graziadei, supra note 1 (the most important factors in the movement of law are power, prestige, and economic efficiency). 
transnational movement of law has replaced all straightforward distinctions of legal family. ${ }^{60}$ It is not the intrinsic differences between legal families, but the concatenation of different mechanisms of diffusion operating along and across the lines of institutional complementarity, linguistic familiarity, professional and educational affinity ties, and adherence to shared spheres of political influence, that lead to divergent or convergent outcomes. ${ }^{61}$

\section{B. Translating}

Legal translation is always an exercise in conceptual translation. ${ }^{62}$ The defining characteristics of different legal systems lie not only in linguistic differences, but also in the "structures of interpretation and meaning" that develop through legal education and practice and sheer repetition within the legal community, the courts, and the polity at large. ${ }^{63}$ Linguistic and conceptual equivalence in the translations between different legal systems is as unobtainable as it is between different literary traditions; the issue is not to find the right translation but instead to find a translation that is least wrong. ${ }^{64}$ This problem is as clear in the field of international politics as it is in the field of international law. When writing to Premier Nikita Khrushchev in November 1961, President John F. Kennedy expressed his predicament very cogently when he wrote:

I am conscious of the difficulties you and I face in establishing full communication between our two minds.

60. Michaels, supra note 33, at 780-81 ("Even if defined in the narrow sense as systems with both common and civil law influences, mixed systems are the norm rather than the exception"); La Porta, Lopez-de-Silanes \& Shleifer, supra note 7, at 309 ("To reiterate, no country exhibits a system of social control that is an ideal type; all countries mix the two approaches. Common law countries are quite capable of civil law solutions, and vice versa.").

61. See Brake \& Katzenstein, supra note 3; see generally Gunther Teubner, Legal Irritants: Good Faith in British Law or How Unifying Law Ends Up in New Divergences, 61 MOD. L. REV. 11 (1998) (arguing that legal transplants irritate law's 'binding arrangements," triggering new and unexpected events).

62. Langer, supra note 16, at 5-6; Sacco, supra note 57, at 12-16; see Gillespie, supra note 33 , at 686 .

63. See Langer, supra note 16, at 9-11. For a paired comparison of translating and transplanting in the case of Britain and France, see J.W.F. ALLISON, A CoNTINENTAL DISTINCTION IN THE COMMON LAW: A HisTORICAL AND COMPARATIVE PERSPECTIVE ON English PUblic LaW (1996); SÁNDOR HERVEy \& IAN HigGins, THINKING Translation: A COURSE IN TRANSLATION METHOD: FRENCH TO ENGLISH (1992).

64. See Susan BassnetT-MCGuire, Translation Studies 37-38 (1980). 
This is not a question of translation but a question of the context in which we hear and respond.... [T] hese differences create a great gulf in communications because language cannot mean the same thing on both sides unless it relates to some underlying purpose. ${ }^{65}$

Thus, translation problems do not occur only when states act in their capacities as the guardians of law. Translation problems arise also within the discursive politics and political struggles that mark legal change in practices that often lie beyond the confines of the state. ${ }^{66}$

The problem of legal translation can occur even within a single cultural context operating with a shared language and uniform legal tradition. ${ }^{67}$ For example, the simple task of "translating English legal language into standard[, comprehensible] English" prose poses considerable difficulties when "legal phrases or terms are imprecise or open to interpretation." 68 Translation problems are compounded by the existence of false legal cognates and the fact that the cognitive relationship "between word and concept is often not identical in . . . different legal languages." 69 Even though U.S. and British legal systems share many important similarities, legal standards and burdens of proof can vary. ${ }^{70}$ The difficulties of successful legal translation arise also outside the English-speaking world. Austrian German and German

65. Letter From President Kennedy to Chairman Khrushchev (Nov. 16, 1961), quoted in Matthew Hill, Introduction, in The Languages of SecuRity IN THE AsIA-Pacific: Case STUDIES (Desmond Ball et al. eds., forthcoming 2013). The concept of translation exists also in organizational sociology typically focusing on practices more generally. See JOHN L. CAMPBELL, INSTITUTIONAL CHANGE AND GLOBALIZATION 79-86, 163-67 (2004) (discussing translations in mechanisms for change).

66. See John Gillespie, Towards a Discursive Analysis of Legal Transfers into Developing East Asia, 40 N.Y.U. J. INT'L L. \& POL. 657, 659-61 (2008).

67. See M.H. Hoeflich, Translation \& the Reception of Foreign Law in the Antebellum United States, 50 AM. J. COMP. L. 753 (2002) (discussing that even with a shared language of English there were issues with translations of texts from other languages from which lawyers could learn from).

68. See Sylvia A. Smith, Culture Clash: Anglo-American Case Law and German Civil Law in Translation, in VIII TRANSLATION AND THE LAW 179, 180 (Marshall Morris ed., 1995).

69. Sofie M.F. Geeroms, Comparative Law and Legal Translation: Why the Terms Cassation, Revision and Appeal Should Not Be Translated, 50 AM. J. CoMP. L. 201, 202 (2002).

70. See, e.g., Brid Jordan, The Modernization of English Libel Laws and Online Publication, 14 NO. 7 J. INTERNET L. 3 (2011) (discussing libel law varies and is continuing to change). 
legal languages also differ in important respects. ${ }^{71}$ Similarly, due to broader historical, political, and cultural differences, legal French deployed in France and Africa can differ substantially and generate its own distinctive problems of translation. ${ }^{72}$ Languages and legal sublanguages thus coexist. Legal translations occur between British English and American English, German German and Austrian German, and French French and Francophone French. ${ }^{73}$

The problem of translation is similarly acute in the field of international law. The Agreement Establishing the World Trade Organization, for example, exists in three original versions-English, French, and Spanish-with each considered to be equally authentic, even though they embody unavoidably different textual meanings. ${ }^{74}$ Similarly, the French law of légitime defense has developed a much richer approach to self-defense than can be found in the English-language case law..$^{75} \mathrm{It}$ is therefore very important whether one follows the French or the English version of the United Nations Charter Article 51 limiting the use of force. ${ }^{76}$ In the context of diplomatic negotiations, differences in interpretations can narrow but not resolve altogether such translation problems. And like international diplomacy, legal translation records and creates ongoing conversations and negotiations among actors in search of practical solutions. In doing so it establishes contingent and evolving systems of shared reference.

The ubiquity of English as a lingua franca is of great relevance to issues of translation. Today, native speakers and foreign-language users of English total about one-fifth of the world's population, with the largest national concentration now living in China. ${ }^{77}$ Communities of lawyers, judges, and academics can no longer ignore the currents of thought expressed in U.S. or common law and scholarship, thus accelerating the rapid spread of the legal theories and practices in both public and private law iterations of common (rather than civil) law. Indeed, the preeminent role of English is increasingly marginalizing all legal systems that do not articulate their rules, judgments, and

71. Uwe Kischel, Legal Cultures-Legal Languages, in TransLATION ISSUES IN LANGUAGE AND LAW 7, 9 (Frances Olsen, Alexander Lorz \& Dieter Stein eds., 2009).

72. See Evandro MEnEzes de CaRvalho, SEmiotics of InTERnational LaW 77 (2011).

73. See Kischel, supra note 71 , at 9 (discussing German and English).

74. See MENEZES dE CARVALHO, supra note 72 , at xvi.

75. George P. Fletcher \& Jens David Ohlin, Defending Humanity: When Force IS JUSTIFIED AND WHY at viii (2008).

76. Id.

77. See David Crystal, English as a Global Language 4-5 (1997) (listing statistics of the number of English speakers). 
commentaries in English. To cite just one example, though the fundamental rights provisions of the South African constitution of 1994 are modeled on the German Basic Law, they are increasingly interpreted with regard to the more accessible English-language material emanating from common law systems. ${ }^{78}$

\section{The SpRead of U.S. Criminal Procedure INTo Domestic Legal SPHERES}

David Hume once noted that "there are in every case very great obstacles to the transferring of the Criminal Law of any one nation to another."79 Though obstacles to the movement of law remain, even in the radically transformed legal landscape of the twenty-first century, Hume's comment overlooks the considerable degree to which criminal procedure laws have spread successfully to new jurisdictions. ${ }^{80}$ There are many theoretical and empirical reasons to expect, as Hume did, that transnational efforts to reform criminal procedure will fail. Firstly, procedural laws comprise the characteristic features of a legal family. It follows, some scholars maintain, that the movement of criminal procedure between legal families is something to fear due to risks of generating "the constitutional equivalent of introducing rabbits into Australia." ${ }^{11}$ Secondly, criminal procedure is linked to the ability of a central government to exert control over its citizens-i.e. "high politics"-and thus should be relatively immune to transnational forces. ${ }^{82}$ Rules governing the rights of accused criminals lie close to issues related to national security, leaving many to expect foreign actors to be ineffective advocates for change. ${ }^{83}$ Beth Simmons, for example, notes that criminal procedural rights have broad implications for the coercive abilities of a political regime. ${ }^{84}$ As such, governments are likely

78. Oliver Brand, Language as a Barrier to Comparative Law, in TRANSLATION ISSUES IN LANGUAGE AND LAW, supra note 71, at 18, 20.

79. David Hume, CommentaRies on THE LAW OF SCOTLAND RESPECTING CRIMES 16 (The Law Society of Scotland reprt. ed. 1986) (1819).

80. See WATSON, supra note 1, at 105.

81. Sklansky, supra note 42, at 1678 (quoting Ronald J. Allen \& Ross M. Rosenberg, The Fourth Amendment and the Limits of Theory: Local Versus General Theoretical Knowledge, 72 ST. JoHN's L. REv. 1149, 1161 (1998)).

82. See Robert Gilpin, The Politics of Transnational Economic Relations, Transnational Relations AND World POlitics 33 (Robert O. Keohane \& Joseph S. Nye, Jr. eds., 1973).

83. See Beth A. Simmons, Mobilizing for Human Rights: International LaW in DOMESTIC POLITICS 15 (2009).

84. Id. 
to avoid international commitments that might "endanger their grip on power or the 'stability' of the broader polity." 85

Though the transnational movement of criminal procedure is multidirectional and comprised of a diverse cast of legal entrepreneurs, the influence of U.S. law is observable in the spread of two legal practices associated with criminal justice in the United States: trials by jury and the plea bargain. The popularity of jury trials, described by the U.S. Supreme Court as "fundamental to the American scheme of justice," 86 has surged in recent years among a diverse set of legal systems, despite popular perceptions of the institution as a key source of the long delays and great costs associated with adversarial trials. ${ }^{87}$ Currently, at least fifty-four countries use jury trials, including Russia and Spain, which recently reintroduced jury trials, as well as South Korea as of 2008, and the newly independent Georgia, which enacted legislation enabling jury trials in 2009 and held its first jury trial in $2011 .{ }^{88}$ In many instances, the socialization of foreign legal scholars from post-authoritarian countries at U.S. law schools, ${ }^{89}$ at conferences, ${ }^{90}$ or through collaborative research networks, ${ }^{91}$ drives the spread of the jury trial. As an anecdotal example, Makheil Saakashvili, the third President of Georgia and former Minister of Justice, pursued advanced degrees in law at Columbia University and George Washington

85. Id.

86. Duncan v. Louisiana, 391 U.S. 145, 149 (1968).

87. Lempert, supra note 3 , at 478 .

88. Nancy S. Marder, An Introduction to Comparative Jury Systems, 86 CHI.-KENT L. REv. 453, 454 (2011) (discussing Russia and Spain, among others); Park, supra note 6, at 530 (outlining the reforms in South Korea); Neil Vidmar, A Historical and Comparative Perspective On the Common Law Jury, in WORLD JURY SYSTEMS 1 (Neil Vidmar ed., 2000) (discussing expansion of the English empire and its introduction of jury trials to different countries).

89. Lempert, supra note 3 , at 480 (noting the spread of juries to the postauthoritarian countries of Japan, Korea, Russia, Spain, and South Africa); Park, supra note 6, at 551-52 (arguing that "legal elites who study and conduct research abroad are the primary conveyers of foreign legal ideas, practices, and institutions," particularly with respect to the spread of the jury trial to Korea).

90. See Valerie P. Hans, Introduction: Citizens as Legal Decision Makers: An International Perspective, 40 CORNELL INT'L L.J. 303, 309-313 (2007) (discussing the role of the Clark Business Law Institute at Cornell Law School in bringing together scholars studying lay participation in Japan, Korea, China, and Thailand).

91. See Marder, supra note 88, at 454 (noting that "the Law \& Society Association (LSA), and in particular its Lay Participation in Legal Systems Collaborative Research Network (CRN) and Lay Participation in Law International Research Collaborative (IRC)," facilitates the transnational movement of scholarship between the United States and foreign jury scholars). 
University. ${ }^{92}$ For its jury system, Georgia contracted the U.S. Center for Jury Studies at the National Center for State Courts to draft a jury management plan, including recommendations regarding procedures for summoning jurors, training court personnel, and orienting individuals to trial by jury. ${ }^{93}$ In some countries, transplanting jury trials has been part of a genuine attempt to embrace democratic reforms and market liberalization, or has been a strategic signal of this embrace. ${ }^{94}$ This postauthoritarian democratization of the judiciary is another instance of transplants extending beyond the legal families distinction. Spain, Portugal, and the province of Córdoba in Argentina have all adopted the jury model even though civil law jurisdictions typically employ mixed tribunals with professional judges and lay persons who sit and decide cases together. ${ }^{95}$

Asia exemplifies both the effects of translating legal procedures and the limits to U.S. legal imperialism. South Korea, which is generally receptive to ideas and practices from the United States, engaged in a process of picking and choosing, translating aspects of both German and U.S. lay participation systems. ${ }^{96}$ Japan investigated both jury and mixed tribunal models before instituting the Saiban-in Seido. ${ }^{97}$ A

92. Biography, THE PRES. OF GEOR. MiKHEIL SAAKASHVILI, http://www.president.gov.ge/en/President/Biography (last visited July 10, 2012).

93. Peter Roudik, Georgia: Courts with Jurors Established Nationwide, LIBR. OF CoNG. GLOBAL LEGAL MONITOR (Nov. 9, 2011), http://www.loc.gov/lawweb/servlet/ lloc_news?disp3_1205402877_text.

94. See generally Hans, supra note 90, at 311 (arguing that the connection between juries and democracy motivates law reform). See also Nikolai Kovalev, Jury Trials for Violent Hate Crimes in Russia: Is Russian Justice Only for Ethnic Russians?, 86 CHI.-KENT L. REv. 669, 680 (2011) (noting that Russia adopted the jury trial, but in 2008 Russian President Medvedev signed a law eliminating the jury trial for those accused of "crimes against the state").

95. See Toby Goldbach \& Valerie P. Hans, Juries, Lay Judges and Trials, in Encyclopedia on CRiminology and CRIMINal Justice (David Weisbrud \& Gerben Bruinsma eds., forthcoming 2012). Mixed tribunals were themselves a product of translation. Initially, the English jury system was transplanted to countries like France and Germany, but the form of lay participation was translated to fit with local inquisitorial criminal procedure. See Kahn-Freund, supra note 19, at 17-18.

96. South Korea imported California's rules on juror note-taking and questioning witnesses, but the number of jurors in South Korea changes in proportion to the seriousness of the crime, and more importantly, the jury is only advisory, with "jury verdicts" acting as recommendations. Park, supra note 6, at 552, 554. See generally Sangjoon Kim, Jaihyun Park, Kwangbai Park \& Jin-Sup Eom, Judge-Jury Agreement in Criminal Cases: The First Three Years of the Korean Jury System, J. EMPIRICAL LeGAL STUD. (forthcoming) (on file with author) (noting that Koreans are skeptical about jury competence but finding that judges and juries agreed on verdicts $91 \%$ of the time).

97. The Saiban-in Seido system in Japan requires that six lay judges and three 
subcommittee of the Osaka Bar Association's Committee for Judicial System Reform toured the United States, Great Britain, and Germany, and several judges of the Supreme Court of Japan traveled to the United States, the United Kingdom, Germany and France.98 Even though Japan had a jury system from 1928 to 1943, it adopted the mixed judge/lay person model more common in civil law jurisdictions. ${ }^{99}$

Surprisingly, the spread of juries has occurred just as their use in America has nearly vanished. Only about two percent of federal criminal cases in 2010 were tried before a jury. ${ }^{100}$ The decline of jury trials in the United States is due largely to the rise of plea bargaining, which, at its simplest, involves a negotiation through which a prosecutor and defense attorney consent to resolve criminal charges without a trial or enter into an agreement over the defendant's punishment. ${ }^{101}$ This device, which allocates considerable power to prosecutors, is not without controversy. Michelle Alexander, a civil rights advocate and associate professor of law at Ohio State University, attributes the United States's "era of mass incarceration" to a system in which more than 90 percent of federal and state convictions are the result of a guilty plea. ${ }^{102}$ Other U.S. scholars have condemned it as "morally and politically unjust." 103 Though jurists overseas have

professional judges decide questions of guilt and sentencing in criminal felony cases. The judgment must be agreed upon by a majority of the panel, with at least one citizen and one professional in the majority. See generally Zachary Corey \& Valerie P. Hans, Japan's New Lay Judge System: Deliberative Democracy in Action?, 12 AsIAN-PAC. L. \& POL'Y J. 72 (2010); Hiroshi Fukurai, Japan's Quasi-Jury and Grand Jury Systems as Deliberative Agents of Social Change: De-colonial Strategies and Deliberative Participatory Democracy, 86 Chi.-Kent L. Rev. 789 (2011).

98. Richard Lempert, A Jury for Japan?, 40 AM. J. CoMP. L. 37, 38-39 (1992) (discussing the feasibility of an Anglo-American jury system or the Continental mixed lay/professional bench for the Japanese legal system).

99. Fukurai, supra note 97, at 801,806 (discussing Japan's passage of the Quasi-Jury Act in 2004 and its move toward a mixed judge/layperson model). Fukurai notes that a mixed lay/judge panel conducted the first-ever trial of a U.S. military serviceman in Okinawa.

100. U.S. District Courts: Criminal Defendants Disposed of, by Method of Disposition (Excluding Transfers), U.S. COURTS (2010), available at http://www.uscourts.gov/ uscourts/Statistics/JudicialFactsAndFigures/2010/Table505.pdf (indicating that only 2,352 of 98,311 federal district court criminal defendants had jury trials).

101. See Black's LAW Dictionary 1270 (9th ed. 2009) (defining the phrase "plea bargain").

102. Michelle Alexander, Go to Trial: Crash the Justice System, N.Y. TIMES, Mar. 10, 2012, available at http://www.nytimes.com/2012/03/11/opinion/sunday/go-to-trial-crashthe-justice-system.html. See also Al Alschuser \& Andrew Deiss, A Brief History of the Criminal Jury in the United States, 61 U. CHI. L. REV. 867, 922 (1994) ("Ninety-three percent of the defendants convicted of felonies in state courts plead guilty.").

103. E.g., Allegra M. McLeod, Exporting U.S. Criminal Justice, 29 YALE L. \& POL'Y REV. 83,118 (2010). 
likewise criticized this quintessentially U.S. practice for the coercive benefits it offers to prosecutors, variants of plea bargaining have spread globally. ${ }^{104}$

The spread of plea bargaining mechanisms is significant because it requires more than a mere procedural change. As a tool tailored for adversarial systems, the movement of plea bargaining from a common to a civil law system transforms the functions of lawyers and challenges popular perceptions of the purpose of the legal system. ${ }^{105}$ Both systems are characterized by different apportionments of power among the principal actors and by different conceptions of the purpose of criminal justice. In adversarial systems, criminal procedure governs disputes between the prosecution and defense before a judge serving as an impartial adjudicator. ${ }^{106}$ In inquisitorial systems, court officials are better understood not as mediators of disputes but as impartial overseers tasked with uncovering the truth. ${ }^{107}$ The guilty plea traditionally did not exist in the inquisitorial model because the truth was for the judge to determine and not something to be negotiated between the prosecutor and defense counsel.108 As Maximo Langer describes, "there are few practices that are more incompatible with the inquisitorial system and the model of the official investigation than plea bargaining." 109

It should be noted that while elements of U.S.-style plea bargaining have spread-from Russia, Georgia, and Bosnia and Herzegovina to Germany, Italy, France, Guatemala, Costa Rica, and Argentina110_ U.S.-style plea bargaining has not arrived in new jurisdictions unchanged. In each new legal system, the device undergoes a process of translation that alters the practice of plea bargaining as well as the receiving legal system itself. ${ }^{111}$ Nonetheless, while a number of plea bargaining regimes that have emerged depart from the U.S. model, the popularity of its basic elements reveals the influence of the United States in the area of legal change.

A survey of recent adopters of plea bargaining suggests the United States wields its influence through means that are both direct (e.g.,

104. See generally Cynthia Alkon, Plea Bargaining as a Legal Transplant: A Good Idea for Troubled Criminal Justice Systems, 19 TRANSNAT'L L. \& CONTEMP. ProBs. 355, 394, 398 (2010) (discussing the proliferation of plea-bargaining).

105. Id. at 356-57.

106. Langer, supra note 16 , at 4 .

107. Id.

108. Id. at $36-37$.

109. Id.

110. Id. at 38; see also Alkon, supra note 104, at 360 .

111. See Langer, supra note 16 , at 3 . 
state-sponsored programs) and indirect (e.g., socialization in classrooms, courtrooms, law firms, and conferences). ${ }^{112}$ In attempting to shape legal development directly, U.S. support ranges from financial support of legal aid clinics to the deployment of prosecutors and law enforcement officers abroad.113 A principal aim of these efforts is to transform the inquisitorial systems of Latin American and ex-Soviet states into close cousins of the adversarial U.S. style. ${ }^{114}$ In the cases of Georgia and Bosnia and Herzegovina, for example, each country received assistance in the form of attorneys sent by the U.S. Department of Justice Office of Overseas Prosecutorial Development, Assistance, and Training. These attorneys, Cynthia Alkon notes, "bring with them certain ideas of how a legal system should work; [f]or many, this includes a system of plea bargaining as a method of case management."115 Since the 1980s, as many as twenty-one Latin American countries received major loan assistance from the United States for criminal procedure reform as well as assistance in the form of technical expertise, legal materials, and training. ${ }^{116}$ By 2006, fourteen of those countries adopted new criminal procedure codes based in part on the U.S. adversarial model.117 Though shepherded into the region in part through an elite network of Latin American lawyers rather than imposed top-down through U.S. efforts, U.S. legal actors "played a crucial role in the spread of [criminal justice] reforms."118

In parts of Europe, the U.S. influence was more indirect. For example, when overwhelming criminal dockets triggered calls for swifter resolution of cases, Italian reformers yielded to the prestige and deep cultural influence of U.S. law and legal scholarship. ${ }^{119}$ This indirect influence has been felt in legal systems around the world through the expansion of U.S. law firms, the growing number of foreign LL.M. students in the United States, the expanding electronic availability of U.S. jurisprudence and scholarship, and the proliferation of U.S.-funded professional associations and standing conferences. ${ }^{120}$

112. See Allegra M. McLeod, Exporting U.S. Criminal Justice, 29 YALE L. \& PoL'Y REv. $83,118(2010)$.

113. See McLeod, supra note 100 , at 84 .

114. Id. at 146.

115. Alkon, supra note 104, at 402 .

116. McLeod, supra note 100, at 119-20.

117. Maximo Langer, Revolution in Latin American Criminal Procedure: Diffusion of Legal Ideas from the Periphery, 55 AM. J. COMP. L. 617, 631 (2007).

118. $I d$. at 646 .

119. See Langer, supra note 16, at $54 \mathrm{n} .263$ (contrasting "American influence" on, or the "Americanization" of, the Argentinean and Italian systems).

120. See Brake \& Katzenstein, supra note 3. 


\section{A. U.S. Criminal Procedure and Legal Reform in China}

To understand the direct and indirect ways through which U.S. criminal procedure law moves into new jurisdictions, it is helpful to examine a "hard case" of legal reform.121 In 1997, when China underwent its first sweeping reform of criminal procedure law (CPL) in the post-Mao era, China adopted the so-called "summary procedure," a practice that resembles aspects of the American plea-bargaining system. ${ }^{122}$ As described below, the surprising adoption of this device is the result of the direct and indirect efforts to expose Chinese legal reformers to U.S. legal norms and practices.

As a civil law country, in which the act of legal innovation falls to legal scholars more than it does to judges, the process of legal reform is best explained through an examination of China's expanding pool of law professors and legal experts. Despite the historical legacy of an inquisitorial legal system and a long-standing suspicion of U.S. rule of law efforts, a survey of legal periodicals suggests that, by the time of the 1997 CPL reforms, China had already developed considerable support for the adoption of U.S.-style plea-bargaining. By the mid-1990s, many scholars were already lauding elements in the U.S. criminal procedure law, such as "the Anglo-American adversarial system" and "AngloAmerican plea-bargaining,"123 while recognizing the foreign roots of these elements. ${ }^{124}$

121. On "hard cases," see StePhen VAn Evera, Guide to Methodology for StUdents OF POLITICAL SCIENCE 30-34 (1996).

122. See Criminal Procedure Law (promulgated by the Second Session of the Fifth Nat'l People's Cong., July 1, 1979, effective as amended Jan. 1, 1997), art. 174-179, http://en.chinacourt.org/public/detail.php?id=2693 (China). The Chinese variant applies where the applicable punishment amounts to less than three years in prison and the prosecutor consents to the use of the summary procedure.

123. See, e.g., Song Yinghui (宋英辉), Lun Woguo Xingshi Susong Zhidu Gaige de Mubiao Moshi-Cong Xingshi Susong Zhidu Biange de Shijiexing Qushi Kan Woguo Xing Su Fa de Xiugai yu Wanshan (论我国形事诉讼制度改革的目标模式一 从形事诉讼制度变革的世界性趋势看我国形诉法的修改与完善] [The Target Model of the Criminal Procedure Reform in China-Analyzing the Amendment and Improvement of the Criminal Procedure Code of China under Global Trends in Criminal Procedure Reform], ZHONGGUO ZHENGFA DAXUE XUEBAO (中国政法大学学报) [JOURNAL OF CUPL] [JOURNAL OF CHINA UNIVERSITY OF POLITICAL SCIENCE AND LAW], no. 5, 1995, at 29, 29-30 (China) (mentioning elements in the U.S. law as something that Chinese legislators can draw lessons from in China's criminal procedure reform).

124. See Yang Xiuli (杨秀莉), Lun Cunyi Bu Qisu (论存疑不起诉) [No Prosecution When in Doubt], HEBEI FAXUE (河北法学) [HBFX] [HEBEI LAW SCIENCE], No. 6, 1997, at 18, 19 (China) (stating that the "no prosecution when in doubt" principle in the Chinese criminal procedure system reflects the principle of judicial efficiency in U.S. law advocated by 
Contrary to Hume's pessimism about the ability of criminal law to move across jurisdictions, Chinese criminal procedure reform reveals the powerful influence of U.S. legal ideas and illustrates the accretive effects of exposure to and interaction with U.S. law. This article describes below the gradual opening of China's legal community to U.S. law and illustrates how this exposure created a body of experts more familiar and comfortable with the U.S. model.

The exposure to U.S. legal practices of the codebooks of the People's Republic of China (PRC) began soon after Mao's death when growing numbers of Chinese scholars began traveling to the United States. ${ }^{125}$ Sponsored by the U.S.-based Committee on Legal Educational Exchange with China (CLEEC), with funding from various U.S.-supported nongovernmental organizations (NGOs), more than 200 Chinese students and scholars participated in legal training in the United States during the 1980s and early 1990s. ${ }^{126}$ By 1988, the Ford Foundation became the first international NGO to establish an office in China. ${ }^{127}$

This growing familiarity with U.S. law grew deeper in subsequent years. As criminal procedure scholar Chen Ruihua described it, beginning in the $1980 \mathrm{~s}$, legal studies in China underwent "a gradual decrease in political interference and ideological restrictions." 128 Chinese universities convened numerous conferences at which U.S. criminal law scholars met with Chinese counterparts. ${ }^{129}$ Participants included representatives of U.S.-supported efforts such as the U.S.-China Rule of Law Initiative, ${ }^{130}$ bar associations, ${ }^{131}$ the Ford Foundation, ${ }^{132}$ and the

Judge Posner).

125. See Pamela Kruger, China's Legal Lion, 29 ThE L. SCH. MAG. 30, 36 (2009).

126. Jacques deLisle, Lex Americana?: United States Legal Assistance, American Legal Models, and Legal Change in the Post-Communist World and Beyond, 20 U. PA. J. INT'L ECON. L. 179, 205 n. 73 (1999).

127. See Yin Deyong, China's Attitude Toward Foreign NGOs, 8 WASH. U. GLOB. STUD. L. REV. 521, 525 (2009).

128. Chen, Ruihua (陈瑞华), Ershi Shiji zhi Zhongguo Xingshi Susong Fa Xue (二十世纪中国之刑車诉讼法学) [Twentieth Century Chinese Criminal Procedure Jurisprudence], ZHONGWAI FAXUE (中外法学) [ZWFX] [CHINESE AND FOREIGN JURISPRUDENCE], no. 6, 1997, at $]$. 16 (1997) (China).

129. See generally Cui, Min (崔敏), Zhongguo Xingshi Susong Fa de Xin FazhanXingshi Susong Fa Xiugai de Quanmian Huigu (中国刑事诉讼法的新发展一 刑事诉讼发修改的全面回顾)(NEW DEVELOPMENTS IN CHINA'S CRIMINAL PROCEDURE LAWA COMPREHENSIVE REVIEW of THE Discussions on THE REVISIONS To THE CRIMINAL PROCEDURE LAW] (1996) (China).

130. See generally Paul Gewirtz, The U.S.-China Rule of Law Initiative, 11 WM. \& MARY BILL RTS. J. 603 (2003); Matthew Stephenson, A Trojan Horse in China?, in Promoting THE RULE OF LAW ABROAD 191 (Thomas Carothers ed., 2006).

131. The American Bar Association began sending delegations to China through its Asian Law Initiatives Council in 1978, the first led by Stanley Lubman, and continues to date. See generally ABA Rule of Law Initiative: China, ABA, http://www.americanbar.org/ 
Asia Foundation. ${ }^{133}$ In addition to these domestic exchanges, more Chinese legal academics enrolled in U.S. law schools. Before the rule of law became a high profile issue in the U.S.-China governmental agenda in the late 1990s, the CLEEC and other like-minded organizations were sponsoring the U.S. legal education of Chinese academics. ${ }^{134}$ By 2002, students from the CLEEC program headed at least six of China's top law schools. ${ }^{135}$ This biased exposure to U.S. law accounts for why reforms in the field of criminal law include so many common-law terms, such as intent, recklessness, knowledge, negligence, foreseeability, and causation. ${ }^{136}$

As the number of Chinese legal academics familiar with U.S. criminal procedure law grew, so too did the number of institutions through which these ideas could spread. Between 1977 and 1995, the number of law schools in China rose from as few as two to more than one hundred, ${ }^{137}$ many of which engaged deeply with their U.S. counterparts. Among the top ten law schools in China in 2010,138 several were directed by deans with extensive experience in the United States in the form of serving as visiting scholars or publishing in English-language law journals. ${ }^{139}$

advocacy/rule_of_law/where_we_work/asia/china.html (last visited Apr. 29, 2010).

132. The Ford Foundation began supporting efforts to train Chinese scholars in international and comparative law as early as 1979. See Randle Edwards, Thirty Years of Legal Exchange with China: The Columbia Law School Role, 23 CoLUM. J. ASIAN L. 3, 11 (2009).

133. See Stanley Lubman, Looking for Law in China, 20 Colum. J. ASIAN L. 1, 89 (2006).

134. Stephenson, supra note 130 , at 193.

135. See James V. Feinerman, Human Rights in China in the Context of Rule of Law: Hearing Before the See Human Rights in China in the Context of the Rule of Law: Hearing Before the Cong.-Exec. Comm'n on China, 107th Cong. 60 (2002) (statement of James V. Feinerman, James M. Morita Professor of Asian Legal Studies; Assoc. Dean, Int'l and Graduate Programs; Dir., Asian L. and Pol'y Stud., Georgetown Univ. L. Ctr).

136. Ian Dobinson, Criminal Law, in INTROdUCtION To ChINESE LAW 107, 110-111 (Wang Chenguang \& Zhang Xianchu eds., 1997).

137. See John W. Head, Feeling the Stones when Crossing the River: The Rule of Law in China, 7 SANTA ClARA J. INT'L L. 25, 72 (2010).

138. Wu Shulian, Lü Jia \& Guo Shilin, A-List Law Schools in China, SinA (Aug. 1, 2007), http://edu.sina.com.cn//2007-01-08/1747136912.html.

139. Zhu Suli served as the Dean of Beijing University School of Law and served as a visiting scholar at Cornell Law School, Zhu Suli, the Anthony W. and Lulu C. Wang Distinguished Visiting Professor of Law, Presents the 2011 Clarke Lecture, CORNELL UNTVERSITY LAW SCHOOL, http://www.lawschool.cornell.edu/spotlights/Zhu-Suli-Presentsthe-2011-Clarke-Lecture.cfm (last visited Mar. 5, 2013), and published multiple articles. See, e.g., Zhu Suli, Political Parties in China's Judiciary, 17 DUKE J. COMP. \& INT'L L. 533 (2007); Zhu Suli, "Federalism" in Contemporary China-a Reflection on the Allocation of Power Between Central and Local Government, 7 SING. J. INT'L \& CoMP. L. 1 (2003) (Sing.). Han Dayuan, Dean of the People's University School of Law, served as a visiting 
Chinese legal scholars directly involved in criminal procedure reform were among those increasingly exposed to U.S. law. In 1992, Chen Guangzhong, a leading criminal procedure scholar, received funding from China's National Social Sciences Fund to study foreign criminal procedure systems in advance of China's criminal procedure reform. ${ }^{140}$ Chen and his team of scholars were well positioned to play the role of transnational legal brokers. Indeed, as estimated by one senior participant in the research team, roughly one-third of the group led by Chen had prior overseas experience with foreign law. ${ }^{141}$ of the remaining members, almost all had $\mathrm{PhDs}$ in law and extensive exposure to comparative law and the U.S. legal community present in Beijing. ${ }^{142}$

In October of 1993, the Criminal Law Department of the Legislative Affairs Commission (LAC), a body which can delegate legislative drafting to experts, formally tasked the team of scholars led by Chen to compose a first draft of the revised CPL. With the support of the Ford

scholar at Harvard Law School. Han Dayuan, Faculty Directory, Renmin University of China School of Law, RENMIN LAW SCHOOL, http://www.law.ruc.edu.cn/eng/ ShowArticle.asp?ArticleID=20233 (last visited Mar. 5, 2013). Xiao Yongping, Dean of Wuhan University School of Law, served as a visiting scholar at the University of Birmingham and the Max-Planck Institute of Foreign Law and Private International Law, Dean of Wuhan University School of Law on China's First Choice-of-Law Act, SOCIETY FOR CHINESE LAW @ COLUMBIA LAW SCHOOL (Nov. 30, 2011), http://blogs.law.columbia.edu/scl/ 2011/11/28/november-30-2011-dean-of-wuhan-university-school-of-law-on-chinas-first-

choice-of-law-act/, and published Xiao Yongping \& Long Weidi, Selected Topics on the Application of the CISG in China, 20 PACE INT'L L. REV. 61 (2008). Wang Zhenmin, Dean of Tsinghua University School of Law served as a visiting scholar at Harvard Law School and the University of Melbourne, and as a visiting professor at the University of Hawai'i at Manoa and Southern Methodist. Wang Zhenmin, School of Law, Tsinghua University, http://www.tsinghua.edu.cn/publish/lawen/3562/2010/20101218002953706471973/2010121 8002953706471973_html (last visited Mar. 5, 2013). Huang Jin, Dean of the China University of Political Science and Law, served as visiting scholar at Yale University School of Law, Professor Huang Jin, CHINA UNIVERSITY OF POLITICAL SCIENCE AND LAW, http://www.cupl.edu.cn/sites/en/101739/101846/101925/index.html (last visited Mar. 5, 2013), and published Huang Jin et al., Chinese Judicial Practice in Private International Law: 2006, 8 CHINESE J. INT'L L. 715 (2009) (China); Huang Jin \& Du Huanfang, Chinese Judicial Practice in Private International Law: 2003, 7 CHINESE J. INT'L L. 227 (2008) (China); Huang Jin \& Du Huanfang, Chinese Judicial Practice in Private International Law: 2002, 4 CHINESE J. INT'L L. 647 (2005) (China); Huang Jin \& Du Huanfang, Private International Law in the Chinese Judicial Practice in 2001, 2 CHINESE J. INT'L L. 387 (2003) (China). Yao Jianzong, Dean of Jilin University, served as a visiting scholar at the London School of Economics. Sun Nanshen, Dean of Fudan University School of Law, served as a visiting scholar at the University of Wisconsin and the University of Glamorgan (UK).

140. See LaWyers Committee for Human Rights, Opening to Reform?: An ANALysis of China's Revised Criminal Procedure LaW 15 (1996).

141. Interview (Sept. 13, 2010) (on file with author, but names kept confidential because of sensitivities of discussing rule of law issues in China).

142. Id. 
Foundation, it convened several conferences in Beijing with foreign experts, all of whom, one participant recalled, were extremely influential in shaping the views of the research team. ${ }^{143}$ Especially influential were those from the United States and the sources they supplied.144 This influence was due in large part to the linguistic skills of the participants. While some spoke German, Japanese, or Russian, most spoke and read English. ${ }^{145}$ Moreover, at least 70 percent of these scholars already had legal experiences abroad, primarily in the United States. ${ }^{146}$ The more exposure to the United States these scholars had, the more likely they were to incorporate U.S. procedure explicitly into their suggestions for criminal procedure reform. ${ }^{147} \mathrm{By}$ July of the following year, Professor Chen submitted a draft law, almost all of which was adopted, including the plea-bargain-like "summary procedure." 148

This quick survey of criminal procedure reform in the post-Mao period provides an illustration of the direct and indirect means through which the United States affects the development of law in the international system. Much of this power is wielded via traditional means such as generously funded government-led assistance programs like the Office of Overseas Prosecutorial Development, a division of the U.S. Department of Justice that deploys U.S. legal advisors abroad, and U.S. Agency for International Development rule of law initiatives. More subtle - though no less effective-manifestations of this power are felt less directly through U.S.-funded NGOs such as the Ford Foundation and, even more indirectly, through the exposure of foreign legal scholars to U.S. law and scholarship in classrooms, courtrooms, law firms, and conferences.

III. THE SPREAD OF U.S. ADMINISTRATIVE LAW INTO THE INTERNATIONAL LEGAL SPHERE

143. Interview (Sept. 20, 2010) (on file with author, but names kept confidential because of sensitivities of discussing rule of law issues in China).

144. Id.

145. Id.

146. Id.

147. Id.

148. See Zhonghua Remin Gongheguo Xingshi Susong Fa Xiugai Jianyi Gao yu Lunzheng (中华人民共和国刑事诉讼法修改建议稿与论证) [ANNOTATED PROPOSED DRAFT OF THE REVISED CRIMINAL PROCEDURE LAW OF THE PEOPLE'S REPUBLIC OF CHINA] (Chen Guangzhong (陈光中) \& Yan Duan (严端), eds., 1995) (China); FAN CHINGY, THE PRocess OF REVISING THE CRIMinal PRocedure LAW of THE PEOPle's REPUBlid of ChINA 2 (1996), available at http://www.law.unimelb.edu.au/download.cfm?downloadfile=92207810-C72E-11E1-

ABFA0050568D0140\&typename $=$ dmFile\&fieldname=filename. 
A second area to search for the influence of the United States in the transnational movement of public law is the domain of global regulation, where aspects of U.S. administrative law procedures have been translated into the fragmented and varied landscape of global governance. Legal and quasi-legal mechanisms both channel ${ }^{149}$ and order the global economy, ${ }^{150}$ and both formal and informal methods of regulation address transnational concerns relating to the environment, security, health, immigration, and labor. ${ }^{151}$ These issues are governed by a diverse set of governmental and nongovernmental actors, ${ }^{152}$ and through a variety of mechanisms and legal nodes; which fuse private and public, ${ }^{153}$ international and domestic, ${ }^{154}$ and hard and soft approaches to law. ${ }^{155}$ Global regulation includes activities at international institutions, within transnational regulatory networks that include domestic administrative agencies, and through regulatory regimes structured by treaties or other such agreements. ${ }^{156}$

149. Lon L. Fuller, Consideration and Form, 41 CoLUM. L. REV. 799, 801 (1941).

150. See Marc Schneiberg \& Tim Bartley, Organizations, Regulation, and Economic Behavior: Regulatory Dynamics and Forms from the Nineteenth to Twenty-First Century, 4 ANN. REV. L. SOC. SCI. 31, 40 (2008) (noting that financial regulation occurs through the International Accounting Standards Board, bond rating agencies, and technical and managerial standards such as the International Organization for Standardization).

151. See Robert A. Kagan, Globalization and Legal Change: The 'Americanization' of European Law? 1 REG. \& Governance 99, 100 (2007); Saskia Sassen, De-Nationalized State Agendas and Privatized Norm-Making, in Public Governance IN The Age of GLOBALIZATION, 51, 52-53 (Karl-Heinz Ladeur ed., 2004). Examples of global regulatory activity include UN Security Council regulation of movement of arms, food, and money in countries that are subject to sanctions; Security Council listing of individuals whose assets will be frozen under anti-terrorism rules; and World Bank supervision of standards in matters from insurance markets to environmental assessments.

152. See Alfred C. Aman, Jr., Indiana Journal of Global Legal Studies: An Introduction, 1 IND. J. Global Legal STUd. 1, 3 (1993); Anne-Marie Slaughter, Global Government Networks, Global Information Agencies and Disaggregated Democracy, in PUBLIC GOVERNANCE IN THE AGE OF GLOBALIZATION 121, 129-131 (Karl-Heinz Ladeur ed., 2004).

153. See Gunther Teubner, Self-Constitutionalizing TNCs? On the Linkage of "Private" and "Public" Corporate Codes of Conduct, 18 IND. J. GLOBAL LEGAL STUD. 617, 633 (2011). See generally Riles, supra note 10 (showing the similarity in how participants in public and private institutions conceive of their regulatory activities).

154. See Alfred C. Aman, Jr., The Earth As Eggshell Victim: A Global Perspective on Domestic Regulation, 102 YALE L. J. 2107, 2119 (1993).

155. For references that include standards and other nonbinding but forceful governing mechanisms, see, for example, Peer Zumbansen, Transnational Law, in ELGAR ENCYCLOPEDIA OF COMPARATIVE LAW 738, 742 (Jan Smits ed., 2006); Slaughter, supra note 152 , at 137 .

156. See generally Benedict Kingsbury, Nico Krisch, Richard B. Stewart \& Jonathan B. Wiener, Foreword: Global Governance as Administration-National and Transnational Approaches to Global Administrative Law, 68 LAW \& CoNTEMP. ProBs. 1, 20-21 (2005) 
The development of this global regulatory framework is neither a bottom-up extension of domestic administrative law nor a top-down "Americanization" 157 of global law. ${ }^{158}$ It is, rather, marked by "horizontal processes of international diffusion and policy transfer" and sociocultural processes of diffusion, emulation, and network formation. ${ }^{159}$ International advocacy networks ${ }^{160}$ consisting of academic, ${ }^{161}$ business, and professional networks ${ }^{162}$ influence the transfer and reception of U.S. legal procedures. ${ }^{163}$ In constructing a global regulatory framework, state and nonstate actors thus have assisted in transplanting and translating U.S. legal procedures, ${ }^{164}$ specifically U.S. review mechanisms. Among other effects, this has assisted in the creation of an international "juristocracy"165 reflected in a growing reliance on judicial and other adjudicative decision makers as reviewers of public action.

(finding five types of global administration-administration by formal IOs, collective action by transnational networks, distributed administration by national regulators, by hybrid intergovernmental-private arrangements, and by private institutions with regulatory functions); Richard B. Stewart, U.S. Administrative Law: A Model for Global Administrative Law?, 68 LAW \& CONTEMP. PROBS. 63, 69 (2005) (finding three types of international regulatory regimes); Aman, supra note 154, at 2111-16 (discussing "Global Regulatory Discourse").

157. See, e.g., Wolfgang Wiegand, Americanization of Law: Reception or Convergence?, in Legal CulTuRe aND THE LEGAL PRofession 137 (Lawrence M Friedman \& Harry N Scheiber eds., 1996); and Kagan, supra note 151; R. Daniel Kelemen \& Eric C. Sibbitt, The Americanization of Japanese Law, 23 U. PA. J. INT'L ECON. L. 269 (2002).

158. See Stewart, supra note 156.

159. Schneiberg \& Bartley, supra note 150 , at 39.

160. See David Vogel \& Robert A. Kagan, An Intraduction, in DYNAMICS of REgUlatory Change: How Globalization AFFeCtS National REgUlatoRy POLICIES 1, 11 (Robert A. Kagan \& David Vogel eds., 2002).

161. See infra pp. 169-80 (regarding judicial review).

162. See Dezalay \& Garth, Marketing and Selling Transnational 'Judges' and Global 'Experts': Building the Credibility of (Quasi)Judicial Regulation, supra note 16, at 119 (arguing that judges, multinational firms, and business litigators promote U.S. style litigation approach to international commercial arbitration); Schneiberg \& Bartley, supra note 150 , at 40 (explaining that lawyers and consultants act as verifiers of compliance with transnational standards and tailor transnational governance to suit clients' needs).

163. See Sassen, supra note 151, at 63; Ole Hammerslev, The European Union and the United States in Eastern Europe: Two Ways of Exporting Law, Expertise and State power, in LAWYERS AND THE RULE OF LAW IN AN ERA OF GLOBALIZATION supra note 5, at 134, 136.

164. See, e.g., Sassen, supra note 151, at 53; Slaughter, supra note 152, at 129-31.

165. See Carol Harlow, Global Administrative Law: The Quest for Principles and Values, 17 EUR. J. INT'L L. 187, 198 (2006); Nico Krisch \& Benedict Kingsbury, Introduction: Global Governance and Global Administrative Law in the International Legal Order, 17 EUR. J. INT'L L. 1, 9 (2006); see generally HIRSCHL, supra note 2 (discussing a growing global trend toward juristocracy). 
The transplanting of domestic administrative law into international or global activity faces several obstacles. First, domestic administrative law is connected to the specific organization of political administration and the particular choices a state makes with respect to managing its economic, political, cultural, and social goals. ${ }^{166}$ In contrast to company law, 167 investor protection, ${ }^{168}$ or the regulation of hate speech, ${ }^{169}$ administrative law is a diffuse area of law connected to a diverse set of interactions, with the boundaries of what is or is not included differing across states. ${ }^{170}$ In addition, global administration and regulation is often informal, with institutions only having the power to make recommendations, as opposed to binding rules. ${ }^{171}$

An even greater obstacle facing the transplant of U.S. administrative legal procedures into the global sphere is the lack of centralized governing bodies and governed constituencies. ${ }^{172}$ In domestic administrative law, administrative action is defined as state acts that are neither legislative nor judicial (thus requiring some other mechanism for accountability). ${ }^{173}$ The rationale for a domestic administrative law is the protection of individual citizens' interests against diffuse decision-making and disciplinary powers. At its core, administrative law is a set of procedural protections or due process

166. See John Bell, Comparative Administrative Law, in THE OxFord HANDBOOK OF COMPARATIVE LAW, supra note 1, at 1259, 1261 ("In one important sense, administrative law includes all of the rules and principles that apply to the administration."); Hanns Peter Nehl, Administrative Law, in ElGAR ENCYClOPEDIA of COMPARATIVE LAW, supra note 155 , at $18,18-19$.

167. See generally, Ron Harris \& Michael Crystal, Some Reflections on the Transplantation of British Company Law in Post-Ottoman Palestine, 10 THEORETICAL INQUIRES IN L. 561 (2009) (discussing the transplantation and harmonization of company law during the British Mandate).

168. See generally La Porta, Lopez-de-Silanes \& Shleifer, supra note 7 (comparing the divergence of investor protection measures in civil and common law countries); Berkowitz, Pistor \& Richard, supra note 33 (surveying investor protection laws in the context of legal families).

169. See generally James Q. Whitman, Enforcing Civility and Respect: Three Societies, 109 YALE L.J. 1279 (2000) (regarding the differences in regulation of hate speech in France, Germany, and the United States).

170. See Jacques Ziller, Public Law, in Elgar Encyclopedia of Comparative LaW, supra note 114 , at 603,604 .

171. Benedict Kingsbury, Nico Krisch \& Richard B. Stewart, The Emergence of Global Administrative Law, 68 LAW \& CONTEMP. PROBS. 15, 53-54 (2005).

172. See Nico Krisch, The Pluralism of Global Administrative Law, 17 EUR. J. INT'L L. 247,250 (2006) (arguing that the label "accountability deficit" is misleading in that organizations and institutions are accountable but may be accountable to the wrong constituencies).

173. Kingsbury, Krisch \& Stewart, supra note 171 , at 17. 
principles to protect "the public interest" as citizens engage with delegated government authority. ${ }^{174}$ These protections may include requirements that notice be given when rights or privileges will be affected by government action, as well as the right to be heard or to make representations, and the right to a review by an impartial adjudicator. All of these measures attempt to control public power based on the rule of law and foundational democratic principles. ${ }^{175}$ Because a state-citizen relationship is absent, ${ }^{176}$ the movement of administrative law to mediate global governing relations is more accurately categorized as a functional translation to control legally binding or effective authority. ${ }^{177}$

Several different types of actors participate in transplanting U.S. legal procedures into global governance. Federal regulatory officials influence the types of procedures adopted when serving on delegations that negotiate transnational or international treaties. ${ }^{178}$ Lawyers act as "brokers," "converting social, political and economic resources into legal processes." 179 In addition, scholars and academics who seek to classify and improve the world around them articulate and crystallize a set of norms that can then be translated into the international arena. ${ }^{180}$ In the case of global governance, scholars are engaged in mapping legal taxonomies onto international institutions and regulatory regimes. Thus

174. See Richard B. Stewart, The Reformation of American Administrative Law, 88 HARV. L. REV. 1669, 1761 (1975); Bell, supra note 166, at 1264; Harlow, supra note 165, at 190.

175. See Harlow, supra note 165, at 191.

176. But see Kingsbury, Krisch, \& Stewart, supra note 171, at 24 (giving examples of impact on private individuals or firms resulting from decisions by international bodies without intervention by governments, including 'UNHCR determinations of individuals' refugee statuses, and certification of NGOs by U.N. agencies").

177. See Benedict Kingsbury, The Concept of 'Law' in Global Administrative Law, 20 EUR. J. INT'L L. 23, 32 (2009); see generally Ralf Michaels, The Functional Method of Comparative Law, in THE OXFORD HANDBOOK OF COMPARATIVE LAW, supra note 1, at 339 (discussing the meaning of functional method of comparative law).

178. See Stewart, supra note 156 , at 78 (using as an example the FDA's implementation of domestic procedure in the importation of foreign products while discussing U.S. delegations).

179. Yves Dezalay \& Bryant G. Garth, Introduction: Lawyers, Law, and Society, in LAWYERS AND THE RULE OF LAW IN AN ERA OF GLOBALIZATION, supra note 11, at 1, 3.

180. See, for example, Catherine Weaver, The Meaning of Development, Constructing the World Bank's Good Governance Agenda, in CONSTRUCTING THE INTERNATIONAL ECONOMY 47 (Rawi Abdelal et al. eds., 2010) and Alvaro Santos, The World Bank's Uses of the "Rule of Law" Promise in Economic Development, in THE NEW LAW AND ECONOMIC Development: A CRITICAL APPRAISAL 253 (David M. Trubek \& Alvaro Santos eds., 2006), for a discussion of the infusion of "good governance" norms into discourse at the World Bank. 
they seek to infuse discussions and decisions regarding international commercial activity and regulation with democratic norms like transparency and accountability. Projects, such as New York University's Global Administrative Law Project, ${ }^{181}$ or the international constitutional law movement, ${ }^{182}$ bring scholars together in conversation to share analysis and solutions to common concerns. ${ }^{183}$

As a result, administrative legal procedures are translated into global governance in three ways. First, procedures may be expressly included in laws, treaties, or other legal structures that coordinate and facilitate cross-border activity, or they may be implied through judicial decisions extending the territorial application of regulations. ${ }^{184}$ Second, as part of efforts to enhance their legitimacy, international organizations and institutions may adopt due process or fairness procedures. ${ }^{185}$ Third, transnational normative networks may be successful in transplanting and translating domestic procedures into norms or values that achieve broad international support. ${ }^{186}$

Scholars of global regulation and administrative law cite several examples of the presence of administrative legal procedures in transnational or international institutions and global regulatory regimes. These include judicial review functions at the European Court

181. See Aman, supra note 152, at 3; Kingsbury, Krisch \& Stewart, supra note 171; Nico Krisch \& Benedict Kingsbury, Introduction: Global Governance and Global Administrative Law in the International Legal Order, 17 EUR. J. INT'L L. 1, 2 (2006); Global Administrative Law Project, INST. FOR INT'L L. \& JUST., http://www.illj.org/GAL/ (last visited Sept. 15, 2012); see generally Kingsbury, Krisch, Stewart \& Wiener, supra note 156 (discussing NYU's Global Administrative Law Project journal symposia).

182. See Jeffrey L. Dunoff \& Joel P. Trachtman, Functional Approach to International Constitutionalization, in RULING THE WORLD?: CONSTITUTIONALISM, INTERNATIONAL LAW, AND Global Governance 3 (Jeffrey L. Dunoff \& Joel P. Trachtman, eds., 2009); See generally VIKRAM DAVID AMAR \& MARK V. TUSHNET, GLOBAL PERSPECTIVES ON CONSTITUTIONAL LAW (2009) (discussing various ways nations resolve contemporary constitutional questions).

183. For an excellent review of the various projects and literatures trying to capture the normative space opened by the global regulatory field, see David Kennedy, The Mystery of Global Governance, in RULING THE WORLD?: CONSTITUTIONALISM, INTERNATIONAL LAW, AND GLOBAL GOVERNANCE, supra note 182 , at 37.

184. See Stewart, supra note 156, at $75-77$ (application of U.S. administrative law directly to actions of international regulatory regimes).

185. Harlow, supra note 165 , at 191.

186. One example here would be broad acceptance of a human rights regime. See Duncan Kennedy, Three Globalizations of Law and Legal Thought: 1850-2000, in THE NEW LAW AND ECONOMIC DEVELOPMENT 66 (2006). Another example would be consensus about judicial independence and strong judicial institutions as a way to support development. See David Kennedy, One, Two, Three, Many Legal Orders: Legal Pluralism and the Cosmopolitan Dream, 31 N.Y.U. REV. L. \& Soc. CHANGE 641, 651 (2007). 
of Justice; 187 notice and comment procedures adopted by the Basel Committee of central banks ${ }^{188}$ and by The Organisation for Economic Co-operation and Development (OECD) and the United States when engaged in international standard setting; ${ }^{189}$ inspection panels at the World Bank investigating allegations of fraud or corruption and allegations of misconduct by staff members; and internal review procedures adopted by the Security Council allowing presentations regarding Al-Qaeda/Taliban asset-freezing sanctions. ${ }^{190}$ One place in particular to look for the influence of U.S. administrative law on global governance mechanisms is the spread of judicial review procedures to settle disputes or assess decisions of state actors and international organizations. Yet, different iterations or institutional models for review compete for primacy in global governance. Moreover, judicial review as a procedure to protect individual rights has a mixed record of reception in the international legal sphere.

\section{U.S. Administrative Law and Judicial Review}

The fragmented quality of U.S. administrative authority finds its origins in the New Deal era when the federal government created a diverse set of independent regulatory agencies, such as the Interstate Commerce Commission and the Environmental Protection Agency, to manage economic growth and social welfare. ${ }^{191}$ U.S. administrative law has several distinctive features, including legal sanctions that allow for civil and criminal penalties for regulatory violations, ${ }^{192}$ detailed and complicated rules prescribing agency rule and decision-making procedures, and public participation (public comment and objections). ${ }^{193}$

187. See Erika de Wet, Holding International Institutions Accountable: The Complementary Role of Non-Judicial Oversight Mechanisms and Judicial Review, 9 GERMAN L.J. 1987, 2001-07 (1988); Harlow, supra note 165, at 195; Kagan, supra note 151 , at 107 .

188. Slaughter, supra note 152, at 313-17; Kingsbury, Krisch, \& Stewart, supra note 171 , at $31-32$.

189. See David Livshiz, Updating American Administrative Law: WTO, International Standards, Domestic Implementation and Public Participation, 24 WIS. INT'L L.J. 961, 968-73 (2007).

190. See Kingsbury, supra note 177 , at 38 .

191. See Nehl, supra note 166, at 25; Kagan, supra note 110 , at 103.

192. Kagan, supra note 151, at 102 (discussing examples of criminal prosecution of corporate officers and prison for environmental offenses).

193. See Robert A. Kagan, The Consequences of Adversarial Legalism, in REgULATORY ENCOUNTERS: MULTINATIONAL CORPORATIONS AND AMERICAN ADVERSARIAL LEGALISM 372 (Robert A. Kagan \& Lee Axelrad eds., 2000) (noting that where both Germany and the United States provided for public comment and objections, public participation under 
Judicial review by ordinary or unspecialized courts as an effort to curtail administrative discretion by threat of judicial reversal of agency decisions, ${ }^{194}$ however, is thought to be one of the most distinctive features of U.S. administrative law. ${ }^{195}$

As NGOs and interest groups use courts as an "alternative policy forum for seeking policy goals," U.S. judges are thought to be "bolder in scrutinizing and reversing governmental plans, regulations, practices, and decisions." 196 Characterized by judicial review and separation of powers, U.S. administrative law stands in contrast to the "bureaucratic legalism" of continental Europe and nonlegalistic, hierarchically-organized modes of policy-making. ${ }^{197}$ Specifically, one can contrast U.S. judicial review with the French model of the administrative judge who works from inside the administration to develop norms and policy, the Scandinavian institution of Ombudsperson, ${ }^{198}$ or the German emphasis on proportionality of decisions (as opposed to a focus on procedural requirements). ${ }^{199}$

The statutory basis for judicial review is found in the Administrative Procedure Act, ${ }^{200}$ enacted in 1946. Initially, judges were restrained in their review, according deference to administrative agencies that were set up during the depression and as part of the New Deal. ${ }^{201}$ National agencies acted under delegated authority that enabled them to carry out executive, legislative, and adjudicative powers to foster regulatory experimentation and "creative expert decisions."202 With growing demands for more activist state involvement in social regulation, throughout the 1960s and 1970s the level of power delegated to administrative agencies increased. ${ }^{203}$ To curtail increased agency

German law was more limited); see generally ROBERT A. KAGAN, ADVERSARIAL LEGALISM: THE AMERICAN WAY OF LAW (2001) (discussing the history of adversarial legalism and connections of the history with American institutions and values).

194. See Harlow, supra note 165, at 198.

195. See Nehl, supra note 166, at 26; Horst Eidenmüller, The Transnational Law Market, Regulatory Competition, and Transnational Corporations, 18 IND. J. GLOBAL LEGAL STUD. 707, 726 (2011) (contrasting United States ex post liability with Continental Europe ex ante control).

196. Kagan, supra note 151 , at 103 (examining judicial participation in civil and common law countries as a possible method of judicial review).

197. See Damaška, supra note 43.

198. Bell, supra note 166, at 1278; Inga Markovits, Exporting Law Reform-But Will It Travel?, 37 CORNELL INT'L L.J. 95, 105 (2004).

199. Harlow, supra note 165 , at 209.

200. See PUB.L. 79.404, 60 STAT. 237 (sections referring to judicial review are codified at 5 U.S.C. $\$ \S 581,701-706(2006))$.

201. See Alfred C. AMAN, JR., ADMinstrative Law in A Global ERA 8 (1992).

202. Id. at 15 .

203. Kagan, supra note 151, at 105. 
discretion, politicians ensured that enabling legislation included detailed rule-making provisions and procedural requirements. These included provisions for giving notice to and allowing comment by affected stakeholders, in addition to making wide allowances for public participation. ${ }^{204}$ At the same time, judicial scrutiny of agency decisions increased and courts extended the meaning of standing to challenge agency action in court, allowing for legal challenges by regulated agencies and NGOs. ${ }^{205}$ From a comparative perspective, U.S. regulation is arguably more adversarial both in the enforcement of regulations, ${ }^{206}$ and in procedures for challenging state action.

Several international organizations and transnational institutions have active judicial review procedures. The Court of First Instance (CFI) of the European Union allowed hearings on EU decisions to implement U.N. Security Council sanctions. ${ }^{207}$ The European Court of Justice (ECJ) extended the meaning of "direct effect" and heard cases brought by advocacy organizations against member states for violations of EU directives on environmental protection. ${ }^{208}$ Not surprisingly, the European transnational courts emulate the Continental model of specialized and separate review courts rather than U.S.-style judicial review. In the case of the ECJ specifically, judicial review of EU action is based on the same concept of legality as the French Conseil d'Etat. ${ }^{209}$ Effectively, review of state action has been written into the North American Free Trade Agreement (NAFTA) under sections 1116 and 1117 , which allow investors to bring claims for breach of substantive obligations. Thus, a developer of a hazardous waste station was able to

204. Martin Shapiro, "Deliberative," "Independent" Technocracy v. Democratic Politics: Will the Globe Echo the E.U.?, 68 LAW \& CONTEMP. PROBS. 341, 356 (2005).

205. See Stewart, supra note 174 , at 1748-56.

206. In a comparative study of multinational corporations operating in OECD countries, most officials and lawyers surveyed conveyed that the legal and regulatory standards were similar, especially around substantive aspects such as safety regulations for labeling and packaging. But case studies have revealed some "counterexamples: (1) instances in which a multinational encountered equal levels or more adversarial legalism in other countries; (2) instances in which there were low levels of adversarial legalism in the United States (and abroad); and (3) regional variation within the United States in the amount or intensity of adversarial legalism." Kagan, supra note 193, at 385.

207. Kingsbury, Krisch \& Stewart, supra note 171, at 32.

208. Kagan, supra note 151 , at 106-07.

209. The grounds for reviewing EU action are based on the same "state-oriented organizing concept" as French review of administrative actions; there are four legality grounds listed in the E.C. Treaty: "lack of competence, infringement of an essential procedural requirement, infringement of [the] Treaty or of any rule relating to its application, or misuse of powers." MITCHEL DE S.-O.-L'E. LASSER, JUDICIAL TRANSFORMATIONS: THE Rights REvolution IN THE COURTS OF EUROPE 229, 235 (2009). 
seek review by a NAFTA tribunal of a Mexican provincial government decision to issue an Ecological Decree for the protection of a rare cactus. ${ }^{210}$ On the other hand, judicial review of arbitration awards under NAFTA may be limited depending on which arbitration rules apply to the investor's claim. ${ }^{211}$ Judicial review by a domestic court is also available to an individual affected by a decision by the International Bureau of the World Intellectual Property Organization (WIPO) regarding the registration of an international trademark. ${ }^{212}$

Some scholars have looked to the procedures and substantive decisions of the World Trade Organization (WTO) for examples of the movement of U.S.-style judicial review into global and transnational regulation. ${ }^{213}$ The WTO has become particularly judicialized through the Disputes Settlement Understanding (DSU), which was included in the Uruguay Round agreements and gives adjudicative tribunals internal to the WTO enhanced binding and final powers of review. ${ }^{214}$ While previous panel reports could be overturned by one veto, reports of the Dispute Settlement Body hold unless there is a unanimous vote to overturn. ${ }^{215}$ The DSU also enables review of panel decisions on issues of law by a standing appellate body. ${ }^{216}$ Nevertheless, in the absence of "direct effect," which would allow individuals rather than governments to bring actions before the WTO, the Dispute Settlement Body and Appellate Body are not true judicial review bodies. ${ }^{217}$

210. Metalclad Corp. v. Mexico, 40 I.L.M. 36 (2001). This NAFTA tribunal decision was further reviewed by an appellate court and upheld in Mexico v. Metalclad Corp., 2001 B.C.S.C. 664 (2001).

211. Gus Van Harten \& Martin Loughlin, Investment Treaty Arbitration as a Species of Global Administrative Law, 17 EUR. J. INT'L L. 121, 134 (2006); see also MARTIN M. Shapiro \& Alec STONE SweET, ON LAW, Politics, AND Judicialization 338-39 (2002) (noting that there is little judicial review of arbitration awards in the United States and that support of foreign arbitrators has hardly waivered).

212. De Wet, supra note 187, at 2000-01.

213. Kingsbury, Krisch \& Stewart, supra note 171, at 17.

214. Understanding on Rules and Procedures Governing the Settlement of Disputes art. 1, Apr. 15, 1994, Marrakesh Agreement Establishing the World Trade Organization, Annex 2, 1869 U.N.T.S. 401, 33 I.L.M. 1226 (1994).

215. Detlev F. Vagts, William S. Dodge \& Harold HongJu Koh, Transnational BUSINESS PROBLEMS 125-49 (4th ed. 2008).

216. Another review measure is found in the WTO Government Procurement Agreement, which allows foreign bidders to challenge domestic government decisions in awarding contracts. See Krisch \& Kingsbury, supra note 165, at 8.

217. See Jeffrey L. Dunoff, The Politics of International Constitutions: The Curious Case of the World Trade Organization, in RULING THE WORLD?: CONSTITUTIONALISM, INTERNATIONAL LAW, AND GLOBAL GOVERNANCE, supra note 182, at 178, 189. 
The WTO appellate body's 1998 review of U.S. regulations requiring shrimp trawling vessels to use approved turtle excluder devices demonstrates the complicated nature of the transnational movement of law. ${ }^{218}$ In contrast to theories about the Americanization of law or unfettered U.S. hegemony in global commerce, the Shrimp Turtle case highlights the potential capture and use of U.S. procedures by competing interests. ${ }^{219}$ U.S. domestic attempts to enact measures to protect the environment are reviewable by judicialized international institutions in much the same way as they would be by a domestic judicial review process. ${ }^{220}$ U.S. influence in the movement of law is thus far from simple. The spread of U.S. administrative law procedures, though substantial, does not ensure a full-scale promotion of U.S. interests through global governance mechanisms. Multiple processes of conflict and competition persist in the production and promotion of law. 221

\section{CONCLUSION: A SOCIAL OPTIC FOR THE ANALYSIS OF THE MOVEMENT OF CRIMINAL AND ADMINISTRATIVE LAW}

The spread of U.S. legal procedures into domestic and international realms is subject to the choices that are embedded in processes of the transplanting and translating of law. Even though the United States is in a superior position to promote its legal procedures, criminal procedure and administrative law do not transplant automatically. They remain subject to processes of translating so as to satisfy local legal language and specific institutional circumstances, as in the case of the movement of legal procedures to international organizations. This article concludes with a brief inquiry into the domestic and international counterparts of the legal domains examined above-the influence of U.S. criminal procedures on international law and the

218. Appellate Body Report, United States - Import Prohibition of Certain Shrimp and Shrimp Products, WT/DS58/AB/R (Oct. 12, 1998) [hereinafter the Shrimp Turtle case].

219. Scholars also point to the Shrimp Turtle case as an example of the transnational movement of other U.S. administrative procedures, in that the Appellate Body requirements included a form of participation or notice and comment procedures for affected countries. Specifically, the Appellate Body found that the United States could have conducted negotiations to conclude bilateral and multilateral agreements before enforcing the prohibition, and it held that there was no transparent or predictable process for certifying turtle excluder devices (TEDs). See id. at 172.

220. Also of note is that the appellate body held that WTO panels are free to consider unsolicited information received from non-WTO members, such as amicus curiae briefs from NGOs. See Stewart, supra note 156, at 93.

221. See Dezalay \& Garth, supra note 179 . 
spread of U.S. administrative law into domestic administrative law systems. Although this article's treatment of these alternate legal domains remains incomplete, it has aimed to highlight the multiple processes of interaction that impact efforts to transplant public law.

Substantive international criminal law has developed at a tremendous pace with the creation of the International Criminal Court (ICC), following the establishment of ad hoc tribunals to address the atrocities in Bosnia, at the International Criminal Tribunal for the former Yugoslavia (ICTY), and Rwanda, at the International Criminal Tribunal for Rwanda (ICTR). ${ }^{222}$ International criminal procedure, however, has developed far more slowly and with far less consensus. While many states quickly arrived at shared understandings of legal standards for genocide and crimes against humanity, the process of developing the procedures by which the international community enforces those standards proved more difficult when legal actors from different legal traditions came together to enforce them. ${ }^{223}$ The international human rights regime that has developed, however haltingly, does not specify whether the legal procedures by which defendants are to be tried should resemble an adversarial, inquisitorial, or some new or hybrid process. ${ }^{224}$ Instead, to garner the support of the greatest number of member states, the various human rights treaties make no guarantees for the right to a trial by jury, nor do they establish firm guidelines concerning the admissibility of evidence or the role of the adjudicator. ${ }^{225}$

The struggle of the international community to find a consensus on matters of procedure is due in large part to the variety of domestic legal traditions of its constituent members. This is not the first time domestic legal traditions have shaped the implementation of international criminal law. At Nuremberg, where the United States and Britain supplied much of the legal procedure applied in the military tribunals, the procedures by which defendants were tried were largely adversarial in origin, except where the adoption of inquisitorial devices rooted in civil law could be used to favor the prosecution. ${ }^{226}$ The development of rules of criminal procedure at the ad hoc tribunals and the ICC similarly reveals the influence of domestic legal traditions in the meting

222. See Gregory S. Gordon, Toward an International Criminal Procedure: Due Process Aspirations and Limitations, 45 CoLUM. J. TRANSNAT'L L. 635, 635 (2007).

223. See id. at 639.

224. See Bert Swart, Damaška and the Faces of International Criminal Justice, 6 J. INT'L CRIM. JUST. 87, 87-88 (2008).

225. See id. at 96.

226. See Gordon, supra note 222, at 642-43. 
out of international justice, as well as the inevitable problems that arise when domestic procedural rules get lost in translation when applied in new settings.

The ICTY statute was the first international criminal tribunal since the Nuremberg and Tokyo trials. ${ }^{227}$ The powerful influence and resources of U.S. actors, such as the American Bar Association, during the early operation of the tribunal, as well as the general ascendance of "adversarial legalism" in legal globalization described above, ensured the adoption of various adversarial methods. ${ }^{228}$ As multiple observers have noted, the procedural rules drew heavily from the Anglo-American tradition, with civil law concepts incorporated into a "predominantly common law framework." 229 Trials at both tribunals, though they differ in important ways, became largely party-driven, adversarial disputes between the prosecution and defendant. ${ }^{230}$ Because the different legal systems pursue different goals-e.g., truth vs. dispute resolution-the confusion caused by the juxtaposition of different legal procedures frustrated many participants in and observers of the international criminal tribunals. One procedural device that triggered considerable confusion when brought into use at an ad hoc tribunal was the allowance of guilty pleas and sentence bargaining. ${ }^{231}$ For example, even though judges expressly denied the inclusion of plea bargaining, prosecutors and defense attorneys nonetheless presented plea agreements to the trial chamber, which did not reject the practice. ${ }^{232} \mathrm{In}$ one instance, a civil law attorney of one defendant at the ICTY interpreted the guilty plea differently from how it is applied in common law systems. As a result, a court of appeals vacated the defendant's conviction and sentence, ruling that he had pleaded guilty without informed consent. 233

227. See Gerry Azzata, Keeping $U p$ with the War Crimes Tribunal: Human Rights Research into the Twenty-First Century, 9 HARV. HUM. RTS. J. 323, 324 (1996) (reviewing VIRGINIA MORRIS \& MICHAEL SCHARF, AN INSIDER'S GUIDE TO THE INTERNATIONAL

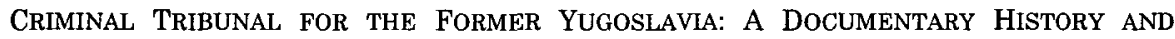
ANALYSIS (1995)).

228. See Frédéric Mégret, Beyond "Fairness": Understanding the Determinants of International Criminal Procedure, 14 UCLA J. INT'L L. \& FOREIGN AFF. 37, 43-44 (2009).

229. Id. at 38 (quoting M. Cherif Bassiouni \& PETER MANIKAS, THE LAW OF THE International Criminal TRIBUnal FOR THE Former YugoslaVIa 955 (1996)); see also Kai Ambos, International Criminal Procedure: "Adversarial", "Inquisitorial" or Mixed?, 3 INT'L CRIM. L. REV. 1, 5 (2003).

230. See Swart, supra note 224 , at 109

231. See Máximo Langer, The Rise of Managerial Judging in International Criminal Law, 53 AM. J. COMP. L. 835, 863-64 (2005).

232. Id. at $865-66$.

233. Id. at 865 . 
The influence of the United States during the drafting of the rules for the ad hoc tribunals and the confusion it created in their translation to the post-conflict setting meant that states negotiating the Rules of Procedure and Evidence for the ICC were unable to reach an agreement over what legal tradition should guide international criminal justice. ${ }^{234}$ Initial drafts of the ICC provided for an adversarial procedure, due again to the significant influence during the drafting process of U.S. lawyers. This adversarial approach, however, did not survive multilateral negotiations that sought to make new rules that were more "international" than they had been at the ad hoc tribunals, as well as to avoid some of the delays inherent to adversarial adjudication. ${ }^{235}$ The final product agreed to by the states, ${ }^{236}$ though argued by some to be a mixed system, ${ }^{237}$ largely avoids the challenge of choosing any particular legal tradition; instead it grants individual adjudicators a considerable amount of discretion to conduct trials according to their preferences and thus avoids the tricky issue of favoring inquisitorial or adversarial devices. 238 As Bert Swart observes, "During the negotiations on the [ICC] Statute, diametrically opposed views between delegations from common law and civil law jurisdictions on the nature of the trial and the duties of parties and judges ... made it impossible to reach agreement on crucial procedural issues." 239 In the end, terms of art associated with one legal tradition or the other were left out of the final drafts of the ICC Statute and the ICC rules of procedure and evidence. ${ }^{240}$

While U.S. influence on international criminal procedure has been substantial, if uneven, the spread of U.S. administrative law domestically has been relatively limited. In the case of domestic administrative law, the importance of legal origin or legal families persists. ${ }^{241}$ Civil law countries that inherited, for example, the French

234. See Swart, supra note 224 , at 102.

235. See Langer, supra note 231, at 837; Mégret, supra note 228, at 64 .

236. It is worth noting the paradox that though the United States voted against the final draft of the ICC Statute, it played a considerable role in the early development of the ICC and it continued to do so by contributing to the development of both the Elements of Crimes and the Rules of Procedure and Evidence. See Megan A. Fairlie, The United States and the International Criminal Court Post-Bush: A Beautiful Courtship but an Unlikely Marriage, 29 BERKELEY J. INT'L L. 528, 531-32 (2011).

237. See Michele Caianiello, Law of Evidence at the International Criminal Court: Blending Accusatorial and Inquisitorial Models, 36 N.C. J. INT'L L. \& CoM. REG. 287, 317 (2011).

238. See Ambos, supra note 229, at 32.

239. Swart, supra note 224 , at 110 .

240. Ambos, supra note 229 , at 20.

241. Bell, supra note 166 , at 1266 . 
tradition of administrative law, have maintained its division between administrative and civil courts. ${ }^{242}$ Countries seeking acceptance into the European Union transplant EU-based rather than U.S. models of administrative law. Reforms, including measures for public participation or access to government information, are guided by EU administrative law experts or voluntary implementation of EU directives. ${ }^{243}$ As former consultants to the Latvian government have noted, in law reform projects, administrative law does not attract the same kind of attention-conceptually or in terms of funding-as other areas of law. ${ }^{244}$ Projects that deal with reforming commercial regulation aim for substantive reforms rather than procedural requirements. ${ }^{245}$ Regulation and reform can also be pursued on a sectorial or agency-by-agency basis, obviating the need for transplanting full administrative law systems. ${ }^{246}$ Moreover, aspects of administrative law that mediate between the citizen and government can be addressed through functional equivalents, ${ }^{247}$ allowing oversight of governmental or quasigovernmental activity and goals for government accountability to occur through other branches of law. ${ }^{248}$

In the decade prior to the sweeping reforms that replaced socialism in Eastern Europe, high court judges and other proponents of law reform transplanted elements of judicial review of administrative decisions. ${ }^{249}$ Since then, there has been scant evidence of U.S. administrative law transplants, even in former Soviet-Bloc countries that have been receptive to other U.S. public law procedures such as trial by jury. Reforms of the Soviet Arbitrazh, which formerly addressed disputes between state-owned enterprises, altered the part-judicial, part-administrative institution into a system of commercial rather than administrative courts. ${ }^{250}$ Similar in structure to Continental Europe's parallel specialized courts, ${ }^{251}$ the Arbitrazh courts deal with business

242. Id. at 1267 (providing examples, including Portugal, Spain, Italy, Belgium, Greece, and former colonies in Africa); Ziller, supra note 170, at 605.

243. Malcolm Russell-Einhorn, Jeffrey Lubbers \& Vedat Milor, Strengthening Access to Information and Public Participation in Transition Countries-Latvia As a Case Study in Administrative Law Reform, 54 ADMIN. L. REV. 459, 463 (2002).

244. Id. at 464

245. Id.

246. Id. at 466 .

247. See Michaels, supra note 177.

248. Ziller, supra note 170 , at 606 .

249. Markovits, supra note 198, at 112-13.

250. Id. at 103-04; Kathryn Hendley, Remaking an Institution: The Transition in Russia from State Arbitrazh to Arbitrazh Courts, 46 AM. J. CoMP. L. 93, 94 (1998).

251. See William Burnham, Peter B. Maggs \& Gennady M. Danilenko, Law and 
complaints against administrative decisions as well as commercial disputes and other traditionally private law matters. In 2001, Latvia enacted administrative law procedures modeled after the German Administrative Procedure Act of 1976. Following the German administrative law tradition, the Latvian act focuses less on procedural matters and more on the appropriateness or proportionality of substantive outcomes. ${ }^{252}$ The Latvian act also provides guidelines for agency decisions rather than imposing a uniform procedure, allowing each agency to adopt procedures accordingly. ${ }^{253}$ In addition, countries have transplanted institutional checks on authority that differ in other ways from U.S.-style judicial review. Originally a Scandinavian innovation, the institution of Ombudsman has been transplanted into both pre-capitalist Poland in 1988 and post-socialist Czech Republic ten years later. ${ }^{254}$

That U.S.-style administrative legal procedures do not appear in other domestic systems may have more to do with constraints on transplanting and translating laws which reflect the nature or type of state power, rather than an outright inability to spread procedural rights or due process principles. ${ }^{255}$ As far as administrative law coordinates the organization and exercise of state power, it embodies features of an activist state devoted to the fulfillment of state programs and the implementation of state policies. ${ }^{256}$ Administrative law thus invokes European legal systems which "attribute a distinctive mission" to public law. 257 The United States is an unlikely donor for this area of law.

The interactional nature of legal development may also mean that processes of transplanting and translating have to contend with extant paradigms of legal thought. Legal culture influences processes of translating as well as donor decisions on how to frame or package legal transplants. Domestic administrative law is closely tied to a period of socially-oriented legal thought (between 1900 and 1968)258 that has

LEgal System of the Russian Federation 50 (3rd ed. 2004); cf. AleXander VERESHCHAGIN, JUDICIAL LAW-MAKING IN POST-SOVIET RUSSIA 12 (2007).

252. Russell-Einhorn, Lubbers \& Milor, supra note 243, at 483.

253. Id.

254. See Markovits, supra note 198, at 105 (arguing that the ombudsman is an institutional mixture of capitalist and socialist legal values).

255 . On the nature or type of state power, e.g. activist (managerial) vs. reactive (conflict resolver), see Swart, supra note 224, at 95.

256. See generally Damaška, supra note 43 .

257. Bell, supra note 166, at 1262.

258. The second period of global legal thought was dominated by Jhering-inspired legal instrumentalist thinking; it saw the provision of social services and presupposed a particular kind of economic, social, and administrative development. Duncan Kennedy, 
since been superseded, more or less, by a period of rights and constitutional engagement. ${ }^{259}$ For Duncan Kennedy, "[h]uman rights are the 'hypostatization' of this trend, operating as universals . . .," functioning "sometimes as rules (even absolute rules) and sometimes as mere policies." 260 Whereas constraint on administrative authority in the past found expression in socially-oriented concepts such as protection of the public interest, presently constraining authoritative action takes place through the language of rights (for example protecting IP rights). ${ }^{261}$ The human rights regime continues to emphasize an independent and impartial judiciary. ${ }^{262}$ Thus the hero figure in this legal world is still the judge. Aspects of judging increasingly come to be seen as transcending national boundaries ${ }^{263}$ in a legal world that promotes human rights and constitutional law as the legal core for domestic and supranational legal systems. ${ }^{264}$

All of the examples of transplanting and translating legal procedures highlight conflict and contestation in the movement of law. When institutional and conceptual possibilities are "at stake," legal actors choose between a set of possible institutional models. ${ }^{265}$ Some legal systems have privileged access to promote the legitimacy of their institutional models. But in some circumstances, for example at the ICC or under the new Latvian administrative act, institutional "ad hocery" exacerbates or promotes competition by creating the institutional circumstances for continued and frequent marketing of legal procedures. Legal syncretism increasingly plays on processes of transplanting and translating legal procedures. Japan stands as a particular example in this regard. Following WWII, Japan may have had a transplant bias to the reception of U.S. law. But more recent and significant changes to Japan's legal system under the Legal System Reform Council, including

Three Globalizations of Law and Legal Thought: 1850-2000, in THE NEW LAW AND ECONOMIC DEVELOPMENT, supra 180, at 19 [hereinafter Kennedy, Three Globalizations].

259. See Alec Stone Sweet, A Cosmopolitan Legal Order: Constitutional Pluralism and Rights Adjudication in Europe, 1 GLOBAL CoNSTITUTIONALISM 53, 60 (2012).

260. Kennedy, Three Globalizations, supra note 258, at 66 .

261. Id. (explaining how human rights play the same role in contemporary legal consciousness that 'social rights' played in the social); see Bell, supra note 166, at 1271 (arguing that the fundamental principles governing administrative law derive from constitutional law because constitutional law establishes the powers and functions of government).

262. Vicki C. JACKSON, Constitutional Engagement In a Transnational ERA 99 (2009).

263. Id. at 65 .

264. Sweet, supra note 259 , at 60 . The institutional instantiation of constitutional judicial review is typically through a separate constitutional court that specializes in protection of rights enumerated in a constitution.

265. Kennedy, Three Globalizations, supra note 258 , at 20. 
the creation of the Saiban-in Seido, evidence the new normal for transplanting and translating law: broad consultation of a range of international models as candidates for legal transplants and facility for translating multiple or even conflicting procedures into instantiations that are uniquely domestic. 266

Existing research will be enriched further and improved upon by investigations into domestic reception and the dynamics incorporating foreign legal norms. For now, this article suggests that the syncretism present in current legal thinking and practice ${ }^{267}$ gives considerable importance to movements of law and institution building, which challenges earlier notions of legalization, legal origin, and power-based views of the impositions of law-pointing instead to a polymorphic legal world with a plurality of options.

266. Kent Anderson \& Trevor Ryan, Japan: The Importance and Evolution of Legal Institutions at the Turn of the Century, in LAW \& LEGAL INSTITUTIONS OF ASIA 120, 125 (E. Ann Black \& Gary F. Bell eds., 2011).

267. Kennedy, Three Globalizations, supra note 258, at 65 (legal syncretism is evident in the "mystical union" of positive and natural law public law; policy analysis does legal work "with whatever materials are left over from the grandiose projects of the past"). 